\title{
Modeling the feedback between aerosol and meteorological variables in the atmospheric boundary layer during a severe fog-haze event over the North China Plain
}

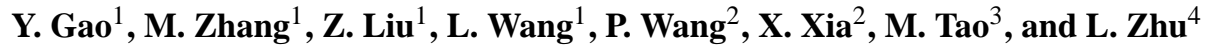 \\ ${ }^{1}$ State Key Laboratory of Atmospheric Boundary Layer Physics and Atmospheric Chemistry (LAPC), \\ Institute of Atmospheric Physics, Chinese Academy of Sciences, Beijing, China \\ ${ }^{2}$ Key Laboratory of Middle Atmosphere and Global Environment Observation (LAGEO), \\ Institute of Atmospheric Physics, Chinese Academy of Sciences, Beijing, China \\ ${ }^{3}$ State Key Laboratory of Remote Sensing Science, Institute of Remote Sensing and Digital Earth, \\ Chinese Academy of Sciences, Beijing, China \\ ${ }^{4}$ Shanxi Province Institute of Meteorological Sciences, Taiyuan, China
}

Correspondence to: M. Zhang (mgzhang@mail.iap.ac.cn)

Received: 24 October 2014 - Published in Atmos. Chem. Phys. Discuss.: 14 January 2015

Revised: 24 March 2015 - Accepted: 26 March 2015 - Published: 24 April 2015

\begin{abstract}
The feedback between aerosol and meteorological variables in the atmospheric boundary layer over the North China Plain (NCP) is analyzed by conducting numerical experiments with and without the aerosol direct and indirect effects via a coupled meteorology and aerosol/chemistry model (WRF-Chem). The numerical experiments are performed for the period of 2-26 January 2013, during which a severe fog-haze event (10-15 January 2013) occurred, with the simulated maximum hourly surface $\mathrm{PM}_{2.5}$ concentration of $\sim 600 \mathrm{ug} \mathrm{m}^{-3}$, minimum atmospheric visibility of $\sim 0.3 \mathrm{~km}$, and 10-100 hours of simulated hourly surface $\mathrm{PM}_{2.5}$ concentration above $300 \mathrm{ug} \mathrm{m}^{-3}$ over NCP. A comparison of model results with aerosol feedback against observations indicates that the model can reproduce the spatial and temporal characteristics of temperature, relative humidity $(\mathrm{RH})$, wind, surface $\mathrm{PM}_{2.5}$ concentration, atmospheric visibility, and aerosol optical depth reasonably well. Analysis of model results with and without aerosol feedback shows that during the fog-haze event aerosols lead to a significant negative radiative forcing of -20 to $-140 \mathrm{~W} \mathrm{~m}^{-2}$ at the surface and a large positive radiative forcing of $20-120 \mathrm{~W} \mathrm{~m}^{-2}$ in the atmosphere and induce significant changes in meteorological variables with maximum changes during 09:00-18:00 local time (LT) over urban Beijing and Tianjin and south Hebei: the temperature decreases by $0.8-2.8^{\circ} \mathrm{C}$ at the surface and increases by
\end{abstract}

$0.1-0.5^{\circ} \mathrm{C}$ at around $925 \mathrm{hPa}$, while $\mathrm{RH}$ increases by about $4-12 \%$ at the surface and decreases by $1-6 \%$ at around $925 \mathrm{hPa}$. As a result, the aerosol-induced equivalent potential temperature profile change shows that the atmosphere is much more stable and thus the surface wind speed decreases by up to $0.3 \mathrm{~m} \mathrm{~s}^{-1}(10 \%)$ and the atmosphere boundary layer height decreases by $40-200 \mathrm{~m} \mathrm{(5-30 \% )}$ during the daytime of this severe fog-haze event. Owing to this more stable atmosphere during 09:00-18:00, 10-15 January, compared to the surface $\mathrm{PM}_{2.5}$ concentration from the model results without aerosol feedback, the average surface $\mathrm{PM}_{2.5}$ concentration increases by $10-50 \mu \mathrm{g} \mathrm{m}^{-3}(2-30 \%)$ over Beijing, Tianjin, and south Hebei and the maximum increase of hourly surface $\mathrm{PM}_{2.5}$ concentration is around $50(70 \%), 90(60 \%)$, and $80 \mu \mathrm{g} \mathrm{m}^{-3}$ (40\%) over Beijing, Tianjin, and south Hebei, respectively. Although the aerosol concentration is maximum at nighttime, the mechanism of feedback, by which meteorological variables increase the aerosol concentration most, occurs during the daytime (around 10:00 and 16:00 LT). The results suggest that aerosol induces a more stable atmosphere, which is favorable for the accumulation of air pollutants, and thus contributes to the formation of fog-haze events. 


\section{Introduction}

The occurrence of fog-haze events has been more frequent in recent years in the developing regions and mega-cities of China. These regions, as determined by visibility observations from the China Meteorological Administration (Che et al., 2007, 2009b; Zhang et al., 2012), include the North China Plain (NCP: Beijing, Tianjin, Hebei province, Shanxi province, and part of Inner Mongolia), and Guanzhong Plain, east China (mainly the Yangtze River Delta area), South China (mostly in the areas of Guangdong and the Pearl River Delta), and the Sichuan basin in southwest China. The North China Plain is one of China's most important social and economic regions; it has a huge population and has undergone rapid development during recent decades. Large emission sources emit primary aerosols and the precursors of secondary aerosols (Zhang et al., 2009; Street et al., 2003), resulting in high loads of aerosols and many aerosol species (e.g., sulfate $\left(\mathrm{SO}_{4}^{2-}\right)$, nitrate $\left(\mathrm{NO}_{3}^{-}\right)$, ammonium $\left(\mathrm{NH}_{4}^{+}\right)$, black carbon (BC), organic carbon (OC), and dust) over the NCP. This is the main reason for the deterioration of visibility and fog-haze events through light extinction (Sun et al., 2006; Chan and Yao, 2008). Based on observational studies (Cheng et al., 2011; Zhao et al., 2013; Quan et al., 2011) during haze periods, the concentration of particulate matter is much higher than on normal days, and fine-mode aerosol is predominant on haze days. Using the RAMS (Regional Atmospheric Modeling System) and CMAQ (Community Multi-scale Air Quality) modeling system (RAMS-CMAQ), Han et al. (2013) showed that the low visibility in December 2010 over the NCP was primarily caused by a high mass burden of $\mathrm{PM}_{2.5}$ as a result of local pollutant accumulation, long-range transport, and $\mathrm{SO}_{4}^{2-}$ and $\mathrm{NO}_{3}^{-}$(the two major inorganic aerosol components of $\mathrm{PM}_{2.5}$ ), decreasing visibility by contributing 40 to $45 \%$ of the total extinction coefficient value.

During 10-15 January 2013, extremely severe fog-haze occurred over the NCP, especially over Beijing, Tianjin, and south Hebei (BTH) with very high aerosol concentration and extremely low atmospheric visibility. The $\mathrm{PM}_{2.5}$ (particulate matter of $2.5 \mu \mathrm{m}$ or less in aerodynamic diameter) concentration at Beijing were $300-800 \mu \mathrm{g} \mathrm{m}^{-3}$ and the air quality index (AQI) was $>300$ (AQI above 300 is considered hazardous to all humans) according to data provided by the Ministry of Environmental Protection of China. January 2013 has been reported as the haziest month of the past 60 years in Beijing, and the reason for its formation draws much attention and is the focus of many studies (e.g., H. Wang et al., 2014; Y. S. Wang et al., 2014; Sun et al., 2014; Zhang et al., 2014; Che et al., 2014; Tao et al., 2014). By analyzing observations from the Campaign on the Atmospheric Aerosol Research Network of China (CARE-China), Y. S. Wang et al. (2014) showed that during 9-15 January 2013 the hourly surface $\mathrm{PM}_{2.5}$ concentration reached $680 \mu \mathrm{g} \mathrm{m} \mathrm{m}^{-3}$ in Beijing, Shijiazhuang (the capital city of Hebei), and Tianjin. It was indicated that a synoptic scale stagnation, unusually cold air, and local metrological conditions (which were extremely unfavorable for the diffusion of air pollutants) were the external reasons, while the rapid transfer from aerosol precursor to aerosol was the main internal reason for this fog-haze event (Y. S. Wang et al., 2014). Sun et al. (2014) showed that the $\mathrm{PM}_{1}$ mass concentration during 10-14 January in Beijing ranged from 144 to $300 \mu \mathrm{g} \mathrm{m}^{-3}$, which was 10 times higher than that during clean periods. They also concluded that stagnant meteorological conditions, coal combustion, secondary production, and regional transport were the four main factors driving the formation and evolution of haze pollution in Beijing during wintertime.

It is known that atmospheric aerosols enhance the absorption and scattering of radiation (direct effect, DE) and act as cloud condensation and ice nuclei that alter cloud properties and precipitation (indirect effect, IE) (Twomey, 1974; Albrecht, 1989). These in turn lead to large decreases in solar radiation reaching the earth's surface, increases in solar heating of the atmosphere, and changes in the distribution of atmospheric temperature structure and precipitation (Ramanathan et al., 2001). It was shown that aerosol DE at the surface was $32.8 \mathrm{~W} \mathrm{~m}^{-2}$ at Xianghe, a suburban site in the $\mathrm{NCP}$, which was comparable to that of cloud radiative effect (Li et al., 2007; Xia et al., 2007). Analysis of a heavy pollution episode in fall 2004 over northern China showed that the instantaneous aerosol DE at the surface reached $350 \mathrm{~W} \mathrm{~m}^{-2}, 300 \mathrm{~W} \mathrm{~m}^{-2}$ of which was absorbed by the atmosphere; therefore, a more stable atmosphere was expected (Liu et al., 2007). Many modeling studies have indicated a decrease in the seasonal/annual average temperature at the surface induced by aerosol over China (Qian et al., 2003; Liu et al., 2010; Wu and Han, 2011; Huang et al., 2006). Wu et al. (2009) used the CAM (Community Atmosphere Model) to simulate the $\mathrm{DE}$ of aerosol $\left(\mathrm{SO}_{4}^{2-}\right.$, dust, $\mathrm{BC}$, and OC) on temperature during 1960-2000 and showed that the surface temperature decreased by about $1.5 \mathrm{~K}$, while atmospheric temperature decreased under $850 \mathrm{hPa}$ and increased in the middle troposphere.

Most of the aforementioned studies focused only on the impacts of meteorological condition on air quality or aerosolinduced meteorological condition changes on climate scale, ignoring the feedback from aerosol-induced meteorological conditions change to aerosol concentration and the change of meteorological variables over shorter time scales (e.g., the diurnal cycle). These may affect the evolution of air pollution, which usually operates over such shorter time scales. In this paper, we estimate the feedback between aerosols and meteorological variables in the atmospheric boundary layer over the NCP during the fog-haze event of 10-15 January 2013 by conducting numerical simulations using a coupled meteorology and aerosol/chemistry model. We begin by introducing the Weather Research and Forecasting model coupled with Chemistry (WRF-Chem), the handling of emissions, and the numerical experiments in Sect. 2, followed by a description 
of the observation data in Sect. 3. Next, we present the model results in Sect. 4: the performance of WRF-Chem when simulating the meteorological variables, surface $\mathrm{PM}_{2.5}$ concentrations, visibility, and aerosol optical depth (AOD) over the $\mathrm{NCP}$; the aerosol impacts on temperature, relative humidity $(\mathrm{RH})$, energy budget, the equivalent potential temperature (EPT) profile, wind, and atmospheric (planetary) boundary layer height (PBLH) during the fog-haze event over the $\mathrm{NCP}$; and the feedback of the above meteorological variables changes to aerosol concentrations. Finally, a summary of the key findings is given in Sect. 5.

\section{Model description}

\subsection{WRF-Chem model}

WRF-Chem is a version of the Weather Research and Forecasting model (Skamarocket al., 2008) that simulates trace gases and aerosol simultaneously with the meteorological fields (Grell et al., 2005). The version used in this study is based on v3.2.1 but with updates including the GOCART (Georgia Tech/Goddard Global Ozone Chemistry Aerosol Radiation and Transport) dust emission coupled with MOSAIC (Model for Simulating Aerosol Interactions and Chemistry) (Zhao et al., 2010) and representation of aerosol direct radiative feedback in the Rapid Radiative Transfer Model for GCMs (RRTMG) (Zhao et al., 2011), which were released in v3.3. All major components of aerosol are treated in the model, including $\mathrm{SO}_{4}^{2-}, \mathrm{NO}_{3}^{-}, \mathrm{NH}_{4}^{+}, \mathrm{BC}, \mathrm{OC}$, sea salt, mineral dust, and aerosol water. Different aerosol species are internally mixed within the mode and externally mixed among different modes. The aerosol scheme includes the representation of physical and chemical processes of emission, nucleation, condensation, coagulation, aqueous-phase chemistry, water uptake by aerosols, and dry and wet deposition. Aerosol optical properties such as extinction, singlescattering albedo, and asymmetry factor for scattering are computed as a function of wavelength and three-dimensional position. Each chemical constituent of the aerosol is associated with a complex refraction index calculated by volume averaging for each size bin (or mode), and Mie theory is used to compute the extinction efficiency $\left(Q_{\mathrm{e}}\right)$ and the scattering efficiency $\left(Q_{\mathrm{s}}\right)$. To efficiently compute $Q_{\mathrm{e}}$ and $Q_{\mathrm{s}}$, WRFChem uses a methodology described by Ghan et al. (2001a) in which the full Mie calculations are first performed to obtain a table of seven sets of Chebyshev expansion coefficients but later are skipped, and $Q_{\mathrm{e}}$ and $Q_{\mathrm{s}}$ are calculated using bilinear interpolation over the Chebyshev coefficients stored in the table. A detailed description of the computation of aerosol optical properties in WRF-Chem can be found in Fast et al. (2006) and Barnard et al. (2010). Bulk hygroscopicity of each size mode/bin, equivalent to $k$ in Petters and Kreidenweis (2007), is based on the volume-weighted average of the hygroscopicity of each aerosol component. The aerosol wet

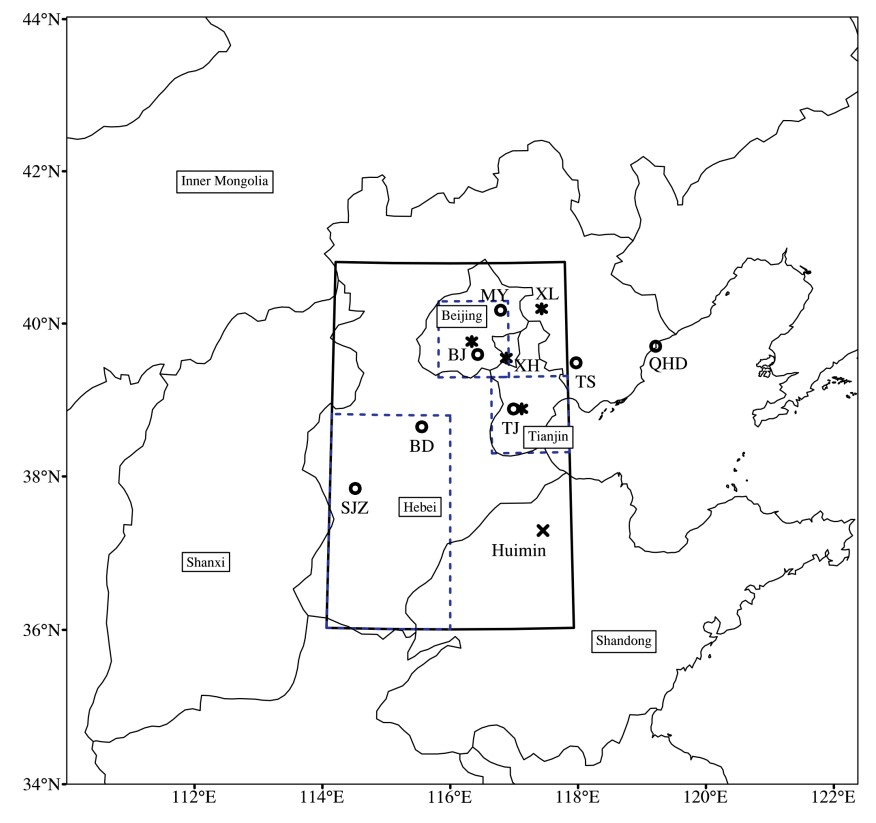

Figure 1. Study domain and regional divisions: Hebei, Beijing, Tianjin, Inner Mongolia, Shanxi, and Shandong. The observation sites (BJ, MY, BD, TS, TJ, QHD, and SJZ) from CNMC are denoted by circles and those from the CARE-China network (BJ, TJ, $\mathrm{XH}$, and $\mathrm{XL}$ ) are denoted by stars, of which BJ and TJ from CNMC and the CARE-China network are very close. The observation sites (BJ, XL, and $\mathrm{XH}$ ) from AERONET have the same locations as those from CARE-China. Huimin site from Che et al. (2014) is denoted by a cross. The black box denotes the region of Beijing, Tianjin, and Hebei (BTH region, $36.2-41^{\circ} \mathrm{N}, 114-118^{\circ} \mathrm{E}$ ), and the three blue boxes with dashed lines denote Beijing, Tianjin, and south Hebei, respectively.

radius is calculated based on Köhler theory. Aerosol-cloud interactions for the aerosol first and second IEs are included in the model by Gustufson et al. (2007) for calculating the activation and resuspension between interstitial aerosols and cloud droplets, which is similar to the method used in the MIRAGE (Model for Integrated Research on Atmospheric Global Exchanges) general circulation model (Ghan et al., 2001b). Aerosol activation is parameterized in terms of updraft velocity and the properties (number, size, and hygroscopicity) of all of the aerosol modes (Abdul-Razzak and Ghan, 2000). The autoconversion of cloud water to rain water depends on cloud droplet number, following Liu et al. (2005).

\subsection{Numerical experiments and emissions}

In this study, WRF-Chem is configured to cover the east part of China $\left(101-134^{\circ} \mathrm{E}, 25-46^{\circ} \mathrm{N}\right)$, with $80(\mathrm{~S}-\mathrm{N}) \times 90$ (W-E) grid points at $27 \mathrm{~km}$ horizontal resolution centering on central China $\left(117^{\circ} \mathrm{E}, 36^{\circ} \mathrm{N}\right)$ and 51 vertical layers up to $50 \mathrm{hPa}$ with 25 layers under $850 \mathrm{hPa}$. Figure 1 shows the study domain used in this paper. The Morrison twomoment bulk microphysics scheme is used to include the 
aerosol IE (Gustafson et al., 2007) and the RRTMG longwave/shortwave scheme is used to include the aerosol DE (Zhao et al., 2011). The carbon bond mechanism and MOSAIC (Zaveri et al., 2008; Fast et al., 2006) are used in this study. MOSAIC uses a sectional approach in which the aerosol size distribution is divided into discrete size bins defined by their lower and upper dry particle diameters. In this study, the aerosol size is divided into eight bins. The initial meteorological fields and boundary conditions are from the National Centers for Environmental Prediction final reanalysis data. Both the initial and boundary chemical conditions are from MOZART's (Model for OZone and Related chemical Tracers) chemical boundary conditions, which are specific to the period being studied.

The simulation is conducted from 14 December 2012 to 26 January 2013, including the time for model spin-up. Two numerical experiments are conducted in order to investigate the feedback between aerosol and meteorological variables. The baseline experiment (EXP_CTL) is conducted by the WRF-Chem model with standard anthropogenic emissions (see Sect. 2.3) and full coupling of aerosol and meteorology simulation. The sensitivity experiment (EXP_NOEF) is conducted by closing the feedback between aerosol and meteorological variables, i.e., by eliminating the aerosol DE and IE in the model. The effect of aerosol on meteorological variables and the feedback of the aerosol-induced meteorological variables changes to aerosol concentrations can be estimated as the difference between EXP_CTL and EXP_NOEF. The model results from EXP_CTL during 2-26 January 2013 are used for the model evaluation, while the difference between the numerical experiment results from 10 to 15 January 2013, the fog-haze period, is analyzed to study aerosol feedback effects.

\subsection{Emissions}

Anthropogenic emissions of carbon monoxide, nitrogen oxides, $\mathrm{SO}_{2}$, volatile organic compounds, $\mathrm{BC}, \mathrm{OC}, \mathrm{PM}_{2.5}$ and $\mathrm{PM}_{10}$ are based on Tsinghua University's 2010 monthly emission inventory (Lei et al., 2011; Zhang et al., 2009; $\mathrm{He}$ et al., 2012), and are added to the diurnal information based on Wang et al. (2010). We use the 2010 $\mathrm{NH}_{3}$ emission from the Regional Emission inventory in ASia (REAS, http://www.jamstec.go.jp/frsgc/research/ d4/emission.htm). Biomass-burning emissions are obtained from the Global Fire Emissions Database v3 (GFEDv3), with monthly temporal resolution (Randerson et al., 2005). Biogenic emission is from the Model of Emission of Gases and Aerosol from Nature (MEGAN) (Guenther et al., 2006). Dust emission is calculated online following Zhao et al. (2010). Sea salt emission is calculated online following Gong et al. (1997) in the publically released version of WRF-Chem. In this study, the sea salt emission scheme is updated following Gong (2003) to include the correction of particles with radius less than $0.2 \mu \mathrm{m}$ and following Jaeglé et al. (2011) to include the sea salt emission dependence on sea surface temperature.

\section{Observation data}

The monitored meteorological data and visibility from the surface stations of the Chinese National Meteorological Center (CNMC; http://cdc.nmic.cn/home.do) were collected to evaluate the performance of the meteorological field simulation. CNMC has 726 measurement stations that are evenly distributed throughout mainland China and has been providing long-term surface observations of several meteorological variables since 1 January 1951 (Feng et al., 2004). The sites used in the study include BJ (54511, Beijing, $\left.39.8^{\circ} \mathrm{N}, 116.47^{\circ} \mathrm{E}\right)$, MY (54416, Miyun, $40.38^{\circ} \mathrm{N}$, $\left.116.87^{\circ} \mathrm{E}\right)$, BD (54602, Baoding, $\left.38.85^{\circ} \mathrm{N}, 115.52^{\circ} \mathrm{E}\right)$, TS (54534, Tangshan, $\left.39.07^{\circ} \mathrm{N}, 118.15^{\circ} \mathrm{E}\right)$, TJ (54527, Tianjin, $\left.39.08^{\circ} \mathrm{N}, 117.07^{\circ} \mathrm{E}\right)$, QHD (54449, Qinhuangdao, $39.85^{\circ} \mathrm{N}, 119.52^{\circ} \mathrm{E}$ ), and SJZ (53698, Shijiazhuang, $\left.38.03^{\circ} \mathrm{N}, 114.42^{\circ} \mathrm{E}\right)$. Each site is denoted by a circle in Fig. 1.

The surface $\mathrm{PM}_{2.5}$ concentrations from 2 to 26 January 2013 are from the CARE-China network (Y. S. Wang et al., 2014), which is located in the Jing-Jin-Ji area. The sites include $\mathrm{BJ}$ (Beijing, $39.97^{\circ} \mathrm{N}, 116.37^{\circ} \mathrm{E}$ ), XL (Xinglong, $40.39^{\circ} \mathrm{N}, 117.58^{\circ} \mathrm{E}$ ), $\mathrm{XH}$ (Xianghe, $39.75^{\circ} \mathrm{N}$, $116.96^{\circ} \mathrm{E}$ ), and $\mathrm{TJ}$ (Tianjin, $39.08^{\circ} \mathrm{N}, 117.21^{\circ} \mathrm{E}$ ), of which $\mathrm{BJ}$ and $\mathrm{TJ}$ are urban sites, $\mathrm{XH}$ is a suburban site, and $\mathrm{XL}$ is considered as the background area of the NCP. Observational sites in the CARE-China network are equipped with RP1400-PM 2.5 or RP1405-PM 2.5 (ThermoScientific: http:// www.thermoscientific.com), which provide a continuous direct mass measurement of particulates by utilizing a tapered element oscillating microbalance (Patashnick and Rupprecht, 1991). Each site is denoted by a star in Fig. 1.

The Aerosol Robotic Network (AERONET) (Holben et al., 1998) is a network of sun- and sky-scanning groundbased automated radiometers providing data on aerosol optical properties (Dubovik and King, 2000; Dubovik et al., 2002). In this study, we use the Level 2.0 AOD data from 2013. The three sites are BJ (Beijing, $39.98^{\circ} \mathrm{N}, 116.38^{\circ} \mathrm{E}$, 30 m.s.l.), XL (Xinglong, $40.39^{\circ} \mathrm{N}, 117.58^{\circ} \mathrm{E}, 940 \mathrm{~m} . s .1$.), and $\mathrm{XH}$ (Xianghe, $39.75^{\circ} \mathrm{N}, 116.99^{\circ} \mathrm{E}, 80 \mathrm{~m} . \mathrm{s} .1$.), which have the same locations as the sites in the CARE-China network.

AOD data at Huimin site $\left(37.48^{\circ} \mathrm{N}, 117.53^{\circ} \mathrm{E}, 11.7\right.$ m.s.l. $)$ from Che et al. (2014), collected from the China Aerosol Remote Sensing Network (CARSNET) and processed using the ASTPwin software offered by Cimel Ltd. (Che et al., 2009a), are also used. This site is denoted by a cross in Fig.1.

The Moderate Resolution Imaging Spectroradiometer (MODIS) aboard the Terra and Aqua satellites covers eastern China twice a day at around 11:00 and 13:00 local time (LT), respectively. The MODIS Collection 6 enhanced Deep Blue 
algorithm provides $10 \mathrm{~km}$ aerosol data over all cloud-free land surfaces except for snow-covered regions, with expected errors within $0.05 \pm 20 \%$ (Hsu et al., 2013). The improved cloud mask method allows more aerosol retrievals in heavy aerosol loading conditions, making Collection 6 aerosol data more suitable for monitoring haze pollution in eastern China.

\section{Results and discussion}

\subsection{Model result for meteorological variables, surface $\mathbf{P M}_{2.5}$ concentration, visibility, and aerosol optical depth}

In this section, a comparison between the model results for temperature, $\mathrm{RH}$, wind, surface $\mathrm{PM}_{2.5}$ concentration, visibility, and AOD from EXP_CTL and the observations during 2-26 January 2013 is presented. Figure 2 are the time series of observed and simulated daily-averaged surface temperature, surface $\mathrm{RH}$, precipitation, surface wind speed, and wind direction at $\mathrm{BJ}, \mathrm{MY}, \mathrm{BD}, \mathrm{TS}, \mathrm{TJ}$, and QHD during 226 January 2013, respectively. The corresponding statistical analysis of the comparisons between simulated and observed temperature, $\mathrm{RH}$, and wind is presented in Table 1. As seen in Fig. 2, the simulated meteorological variables agree well with observations. For the temperature, the model can depict its temporal variation but slightly underestimates the values at $\mathrm{BJ}$ and TJ, with correlation coefficients $(R)$ of 0.78 0.91 and mean bias (MB) of -1.6 to $0.5^{\circ} \mathrm{C}$ at the six sites. The model also reproduces the spatial distribution of temperature: the temperature is minimum at $\mathrm{MY}$ and QHD, of which MY is at the highest latitude and QHD is a coastal site (Fig. 1), while the maximum is at BJ and TJ, which are both urban sites located in big cities. The observed RH is also reasonably reproduced by the model $(R=0.72-0.90$; $\mathrm{MB}=-10.0$ to $-8.8 \%$ ). During $10-15$ January, both the simulated and observed RH are very high, with values ranging from 70 to $90 \%$, especially at $\mathrm{BD}$, TS, TJ, and QHD, which may be influenced by the south and southeast wind flow from more moist areas (Gao et al., 2014). The high RH over the NCP will contribute to the high aerosol concentration and fog-haze event during 10-15 January (Zhang et al., 2014). The model also reproduces the precipitation during 20-21 January but underestimates the values of daily precipitation (Fig. 2). This may be due to the relatively coarse model resolution $(27 \mathrm{~km})$ that is unable to resolve the local variability at each site. There is no precipitation during the fog-haze period (10-15 January). The simulated variation of the maximum and mean wind speed and wind direction in the model agree well with the observation at the six sites $(R=0.51-0.83$ for mean wind speed and $0.22-0.86$ for wind direction). However, the model overestimates the mean wind speed by $0.5-1.9 \mathrm{~m} \mathrm{~s}^{-1}$ at the six sites. This may be due to the out-of-date land surface data in the model which are adopted from 5 min resolution USGS (United States Geolog- ical Survey) 24-category data derived from $1 \mathrm{~km}$ Advanced Very High Resolution Radiometer (AVHRR) measurements in a 12-month period spanning from April 1992 to March 1993 (Loveland et al., 1991; Brown et al., 1993). The USGS data sets may underestimate the urbanization over NCP compared to present-day land surface data (Yu et al., 2012). The maximum wind speed is simulated much better by the model than the mean wind speed $(R=0.60-0.76$, normalized mean bias $(\mathrm{NMB})=6$ to $20 \%)$. The reason may be that the simulated wind speed is instantaneous while the observed mean wind speed is $10 \mathrm{~min}$ averaged. In addition, the out-of-date land surface data mean the small wind speed cannot be well reproduced by model.

Figure 3 shows the time series of hourly surface $\mathrm{PM}_{2.5}$ concentration from the observation and the corresponding model results from EXP_CTL at BJ, XL, XH, and TJ during 2-26 January 2013. The statistical analysis between the model results and observation of surface $\mathrm{PM}_{2.5}$ concentration is shown in Table 1. In general, the model reasonably reproduces the hourly variation of surface $\mathrm{PM}_{2.5}$ concentration during 2-26 January at the four sites $(R=0.56-0.69$, $\mathrm{NMB}=-10.9$ to $59.5 \%$ ). Both the observation and model results show the surface $\mathrm{PM}_{2.5}$ concentration to be highest at $\mathrm{XH}$ and $\mathrm{TJ}$, of which $\mathrm{XH}$ is a suburban site located in Hebei and TJ is an urban site located in Tianjin. Note that although $\mathrm{XH}$ is a suburban site, the surface $\mathrm{PM}_{2.5}$ concentration at this site is comparable to, or even higher than, that at BJ (Fig. 3 and Table 1), which may suggest more pollutants over the southern part of Hebei and transport of pollution to Beijing. The surface $\mathrm{PM}_{2.5}$ concentration is lowest at $\mathrm{XL}$, which is a background site located at the top of a mountain ( 940 m.s.l.) and less affected by anthropogenic activities and more affected by transport compared to other sites. The simulated surface $\mathrm{PM}_{2.5}$ concentration agrees very well with the observation at XL $(R=0.69)$, indicating that the atmospheric transport process is reproduced by the model. The model overestimates the surface $\mathrm{PM}_{2.5}$ concentration at $\mathrm{XH}$ and TJ. In Fig. 3, focusing on the fog-haze period (10-15 January), it can be seen that the event starts from midnight on 10 January, with the surface $\mathrm{PM}_{2.5}$ concentration rising from around 100 to $200-300 \mu \mathrm{g} \mathrm{m}^{-3}$ at BJ, from around 50 to 200 $300 \mu \mathrm{g} \mathrm{m}^{-3}$ at XL, and from 100 to $200-400 \mu \mathrm{g} \mathrm{m}^{-3}$ at XH and TJ. After that, the concentration continues to increase to $200-400 \mu \mathrm{g} \mathrm{m}^{-3}$ at BJ and XL and to $300-500 \mu \mathrm{g} \mathrm{m}^{-3}$ at $\mathrm{XH}$ and TJ, during the day on 11 January. The surface $\mathrm{PM}_{2.5}$ concentration decreases during the night on 11 January at BJ and XL but maintains a high value of $200-500 \mu \mathrm{g} \mathrm{m}^{-3}$ at $\mathrm{XH}$ and TJ. The surface concentration increases again on 12 and 13 January, with a value of $200-400 \mu \mathrm{g} \mathrm{m}^{-3}$ at BJ, 100$200 \mu \mathrm{g} \mathrm{m}^{-3}$ at XL, and $200-500 \mu \mathrm{g} \mathrm{m}^{-3}$ at XL and TJ. During the night of 14 January, the surface $\mathrm{PM}_{2.5}$ concentration begins to decrease to around $50-100 \mathrm{\mu g} \mathrm{m}^{-3}$ at all four sites. The consistent variation of surface $\mathrm{PM}_{2.5}$ concentration at the four sites and the rapid rise of surface $\mathrm{PM}_{2.5}$ concentration at 


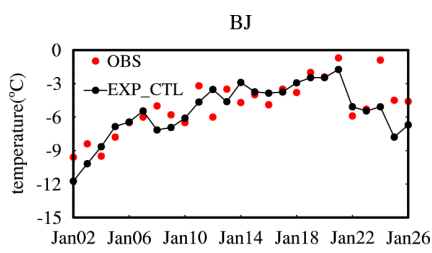

TS

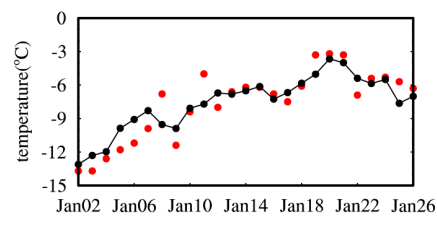

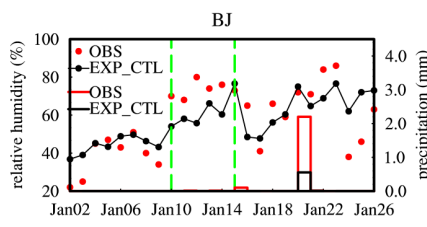

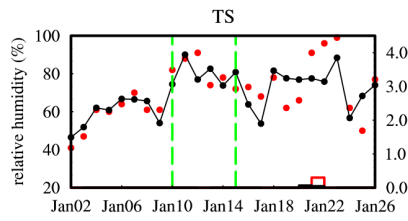

BJ

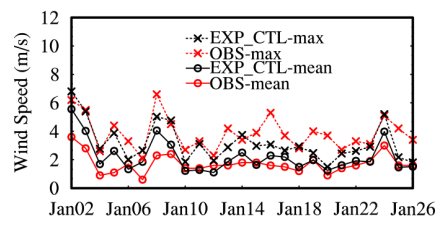

TS
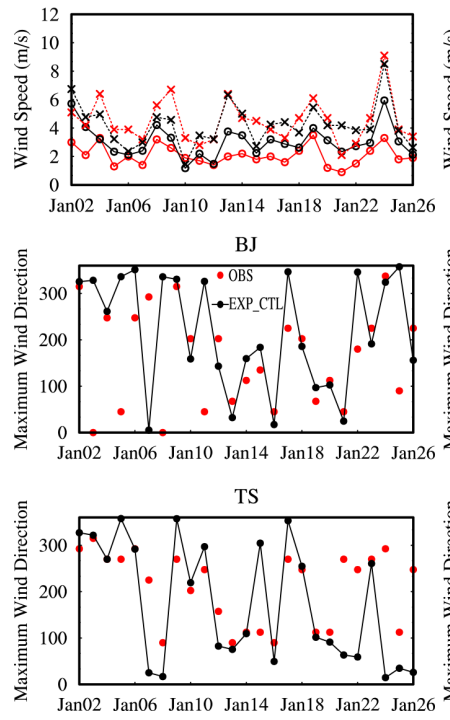

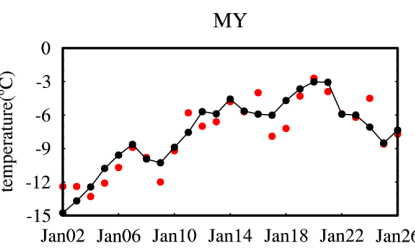

TJ

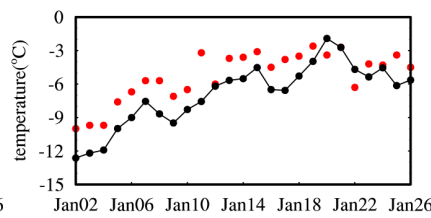

MY
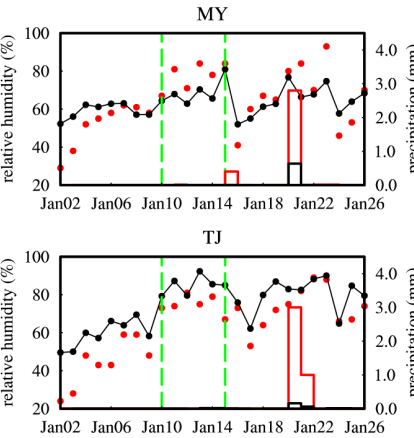

MY

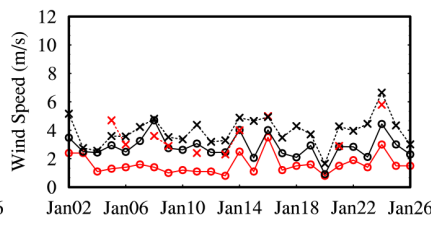

TJ
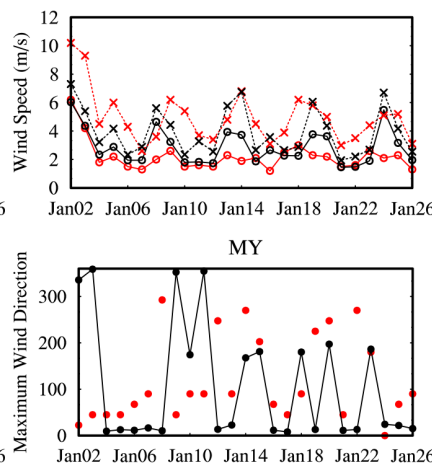

TJ

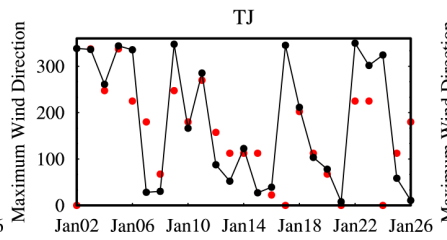

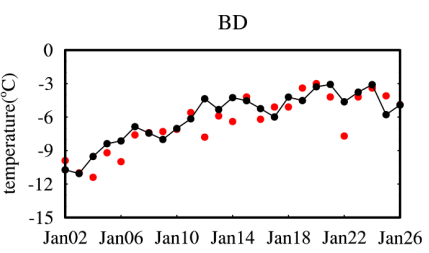

QHD

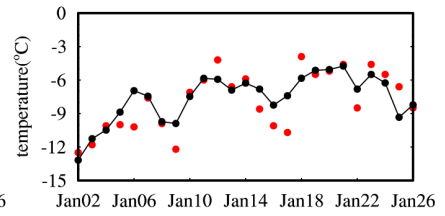

BD
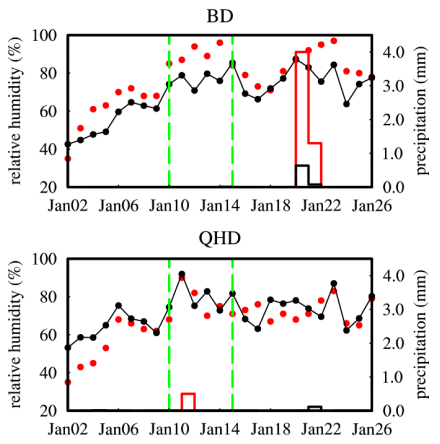

BD

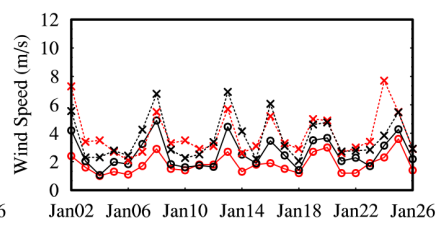

QHD

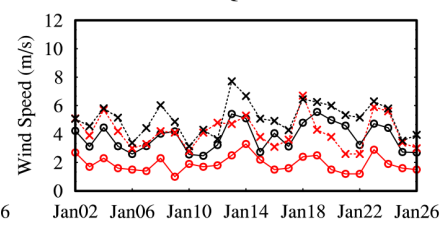

BD

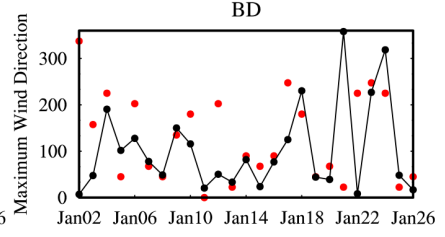

QHD

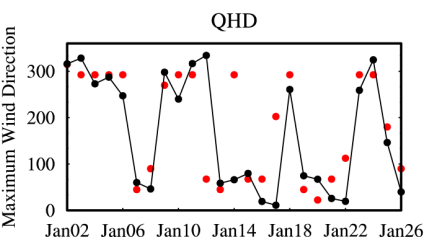

Figure 2. Time series of observed (red) and simulated (black, EXP_CTL) daily-averaged $2 \mathrm{~m}$ temperature $\left({ }^{\circ} \mathrm{C}\right)$, daily-averaged $2 \mathrm{~m}$ relative humidity $(\%)$, daily precipitation $\left(\mathrm{mm}\right.$, bar), daily-averaged $10 \mathrm{~m}$ wind speed $\left(\mathrm{m} \mathrm{s}^{-1}\right.$, solid line), daily $10 \mathrm{~m}$ maximum wind speed (dashed line), and daily wind direction of maximum wind speed at BJ, MY, BD, TS, TJ, and QHD during 2-26 January 2013. 
Table 1. Statistics of the comparisons between simulated and observed temperature $\left({ }^{\circ} \mathrm{C}\right)$, relative humidity $(\mathrm{RH}, \%)$, wind speed (m $\left.\mathrm{s}^{-1}\right)$, surface $\mathrm{PM}_{2.5}$ concentration $\left(\mu \mathrm{g} \mathrm{m}^{-3}\right)$, visibility $(\mathrm{km})$, and aerosol optical depth (AOD) during 2-26 January 2013.

\begin{tabular}{|c|c|c|c|c|c|c|c|c|}
\hline & & $N^{\mathrm{a}}$ & $C_{\mathrm{OBS}}^{\mathrm{b}}$ & $C_{\mathrm{MOD}}^{\mathrm{b}}$ & $R^{\mathrm{c}}$ & $\mathrm{MB}^{\mathrm{d}}$ & $\operatorname{NMB}(\%)^{\mathrm{d}}$ & $\mathrm{RMSE}^{\mathrm{e}}$ \\
\hline \multirow[t]{6}{*}{ Temperature } & $\mathrm{BJ}$ & 25 & -5.0 & -5.5 & 0.78 & -0.5 & 9.0 & 1.6 \\
\hline & MY & 25 & -7.7 & -7.6 & 0.91 & 0.1 & -2.0 & 1.3 \\
\hline & $\mathrm{BD}$ & 25 & -6.5 & -6.0 & 0.86 & 0.5 & -7.2 & 1.3 \\
\hline & TS & 25 & -7.7 & -7.6 & 0.91 & 0.1 & -0.7 & 1.3 \\
\hline & $\mathrm{TJ}$ & 25 & -5.3 & -6.9 & 0.88 & -1.6 & 31.2 & 2.1 \\
\hline & QHD & 25 & -7.9 & -7.6 & 0.83 & 0.3 & -3.4 & 1.5 \\
\hline \multirow[t]{6}{*}{ RH } & $\mathrm{BJ}$ & 25 & 57.6 & 57.1 & 0.72 & -0.4 & -0.7 & 12.6 \\
\hline & MY & 25 & 64.3 & 63.6 & 0.84 & -0.7 & -1.0 & 10.5 \\
\hline & $\mathrm{BD}$ & 25 & 77.5 & 69.1 & 0.87 & -8.4 & -10.8 & 11.0 \\
\hline & TS & 25 & 70.9 & 69.9 & 0.76 & -1.0 & -1.4 & 9.6 \\
\hline & TJ & 25 & 64.2 & 74.4 & 0.90 & 10.3 & 16.0 & 12.8 \\
\hline & QHD & 25 & 67.5 & 71.7 & 0.78 & 4.1 & 6.1 & 8.8 \\
\hline \multirow[t]{6}{*}{ WS } & $\mathrm{BJ}$ & 25 & 1.7 & 2.2 & 0.82 & 0.5 & 27.8 & 0.82 \\
\hline & MY & 25 & 1.6 & 2.8 & 0.64 & 1.2 & 78.7 & 1.4 \\
\hline & $\mathrm{BD}$ & 25 & 1.8 & 2.6 & 0.83 & 0.75 & 40.8 & 1.0 \\
\hline & TS & 25 & 2.1 & 3.1 & 0.68 & 1.0 & 46.4 & 1.3 \\
\hline & $\mathrm{TJ}$ & 25 & 2.2 & 2.9 & 0.65 & 0.7 & 30.9 & 1.2 \\
\hline & QHD & 25 & 2.0 & 3.8 & 0.51 & 1.9 & 100.0 & 2.1 \\
\hline \multirow[t]{4}{*}{$\mathrm{PM}_{2.5}$} & $\mathrm{BJ}$ & 600 & 138.4 & 123.4 & 0.63 & -15.1 & -10.9 & 102.8 \\
\hline & XL & 590 & 49.1 & 62.0 & 0.69 & 12.9 & 26.2 & 44.8 \\
\hline & $\mathrm{XH}$ & 502 & 139.8 & 181.2 & 0.56 & 41.4 & 29.6 & 113.9 \\
\hline & $\mathrm{TJ}$ & 500 & 135.9 & 216.9 & 0.69 & 80.9 & 59.5 & 124.9 \\
\hline \multirow[t]{4}{*}{ Visibility } & BJ & 100 & 11.2 & 16.2 & 0.77 & 5.0 & 44.5 & 10.3 \\
\hline & $\mathrm{TJ}$ & 100 & 8.0 & 8.1 & 0.66 & 0.1 & 0.95 & 6.0 \\
\hline & $\mathrm{BD}$ & 100 & 6.5 & 7.2 & 0.58 & 0.7 & 10.5 & 5.8 \\
\hline & SJZ & 100 & 5.8 & 5.7 & 0.43 & -0.1 & -2.8 & 5.1 \\
\hline \multirow[t]{4}{*}{ AOD } & BJ & 22 & 0.52 & 0.42 & 0.59 & -0.10 & -20.2 & 0.34 \\
\hline & XL & 12 & 0.23 & 0.34 & 0.99 & 0.11 & 47.2 & 0.12 \\
\hline & $\mathrm{XH}$ & 16 & 0.64 & 0.41 & 0.60 & -0.23 & -36.7 & 0.47 \\
\hline & Huimin & 18 & 0.96 & 0.73 & 0.74 & -0.22 & -23.3 & 0.50 \\
\hline
\end{tabular}

${ }^{\text {a }} N$ is the number of paired samples; ${ }^{\mathrm{b}} C_{\mathrm{OBS}}$ and $C_{\mathrm{MOD}}$ are the monthly average values of observation and model results, sampled at the observation site and time, respectively; ${ }^{\mathrm{C}} R$ is the correlation coefficient between the observation and model results; ${ }^{\mathrm{d}} \mathrm{MB}$ and NMB are the mean biases between the observation and model results and the normalized mean bias between the observation and model results, respectively; ${ }^{\mathrm{e}}$ RMSE is the root-mean-square error of observation and model results.

XL suggest that the fog-haze event of 10-15 January 2013 was regionally distributed.

Figure 4 is the time series of hourly visibility at 00:00, 06:00, 12:00, and 18:00 from CNMC measurements and the corresponding WRF-Chem simulation at $\mathrm{BJ}, \mathrm{TJ}, \mathrm{BD}$, and SJZ during 2-26 January 2013. The visibility is calculated as $3.912 /$ aerosol extinction coefficient at $550 \mathrm{~nm}$. The impacts of gas phase molecules on visibility include Rayleigh scattering of air, and the absorptions of $\mathrm{O}_{3}, \mathrm{NO}_{2}$, and $\mathrm{SO}_{2}$ of solar radiation are small compared to the droplets and particles under heavy aerosol loading conditions. As a result, their effects on visibility are ignored in this study (Deng et al., 2008; Quan et al., 2011). The simulated aerosol extinction coefficient at $550 \mathrm{~nm}$ is calculated by using the de- fault output AOD and Angstrom exponent derived from the output AODs at 400 and $600 \mathrm{~nm}$. Therefore, the evaluation of the modeled visibility also reflects the evaluation of the modeled aerosol concentration and optical properties. From Fig. 4 and Table 1, the visibility is reproduced well by the model $(R=0.77,0.66,0.58$, and 0.43 and $\mathrm{MB}=5.0,0.1$, 0.7 , and $-0.2 \mathrm{~km}$ at the four sites). The model overestimates the visibility at $\mathrm{BJ}$, and the overestimation is mainly due to the overestimation of visibility on clear days. This may be caused by the bias of the modeled extinction coefficient and aerosol mass concentration. Nevertheless, the model is able to capture the deterioration of visibility on polluted days at the four sites. Both the observation and model results show the value of visibility to be very low (around $1-3 \mathrm{~km}$ ) during 
BJ

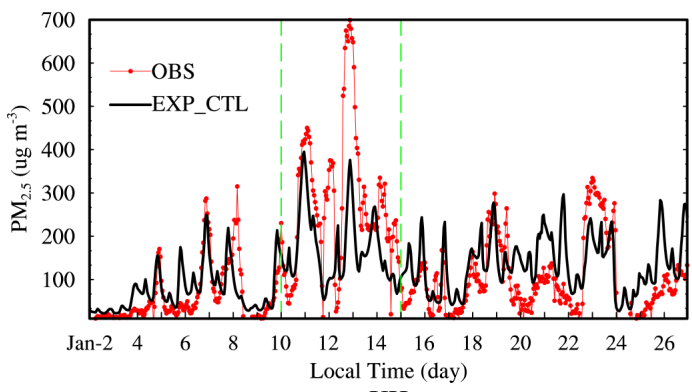

$\mathrm{XH}$

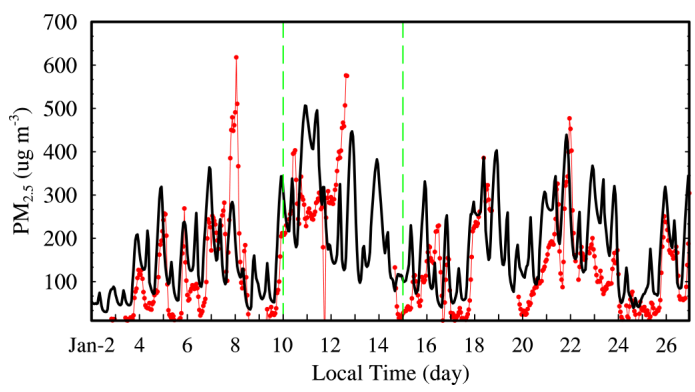

$\mathrm{XL}$

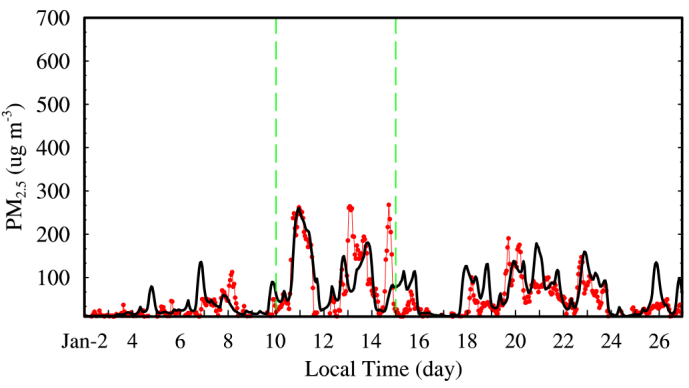

TJ

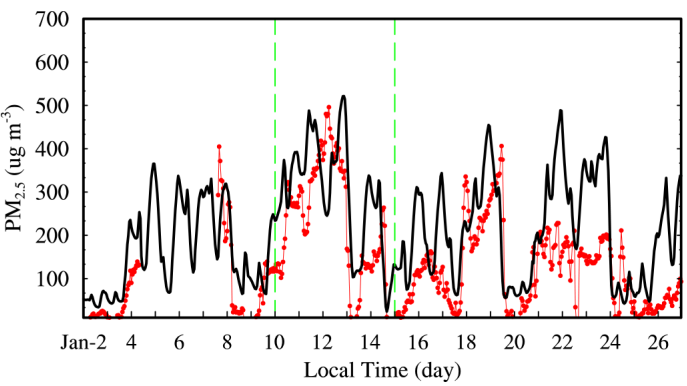

Figure 3. Time series of hourly surface $\mathrm{PM}_{2.5}$ concentration $\left(\mu \mathrm{g} \mathrm{m}^{-3}\right)$ from the CARE-China network measurement and the corresponding WRF-Chem simulation (EXP_CTL) at BJ, XL, XH, and TJ during 2-26 January 2013.
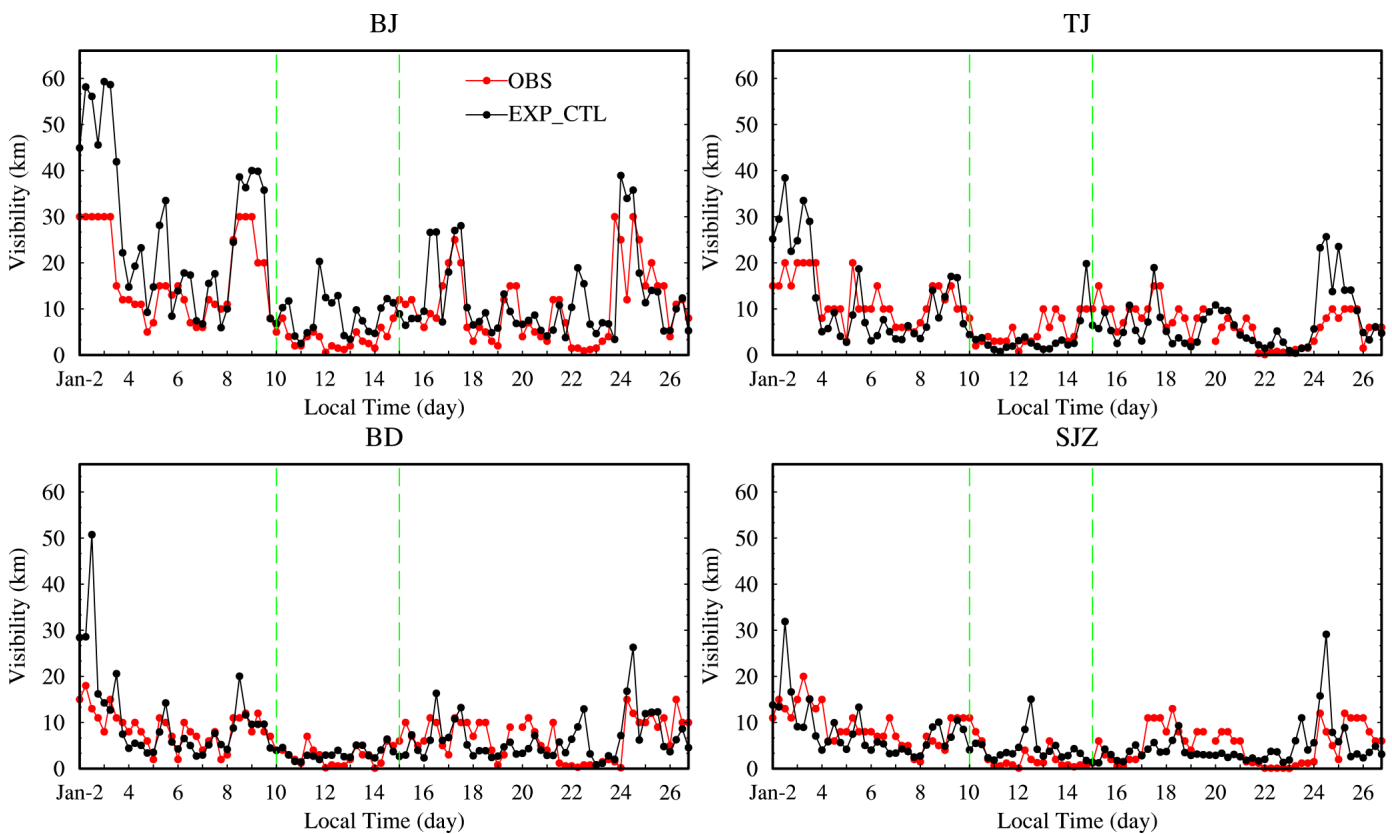

Figure 4. Time series of hourly visibility $(\mathrm{km})$ at 00:00, 06:00, 12:00, and 18:00 from CNMC measurements and the corresponding WRFChem simulation (EXP_CTL) at BJ, TJ, BD, and SJZ during 2-26 January 2013.

10-14 January. However, the model overestimates the visibility at BJ on 12 January, which may be due to the underestimated surface $\mathrm{PM}_{2.5}$ concentration that day (Fig. 3).

Figure 5 is the time series of daily AOD at $550 \mathrm{~nm}$ at $\mathrm{BJ}, \mathrm{XL}$, and $\mathrm{XH}$ from the AERONET measurements and at Huimin site from Che et al. (2014), MODIS Deep Blue
AOD retrievals, and the corresponding WRF-Chem simulation during 2-26 January 2013. The simulated AOD at $550 \mathrm{~nm}$ is calculated by using the Angstrom exponent derived from the default output AODs at 400 and $600 \mathrm{~nm}$. As the MODIS aboard the Aqua satellite covers eastern China at around 13:00 local time, the simulated AOD at 13:00 

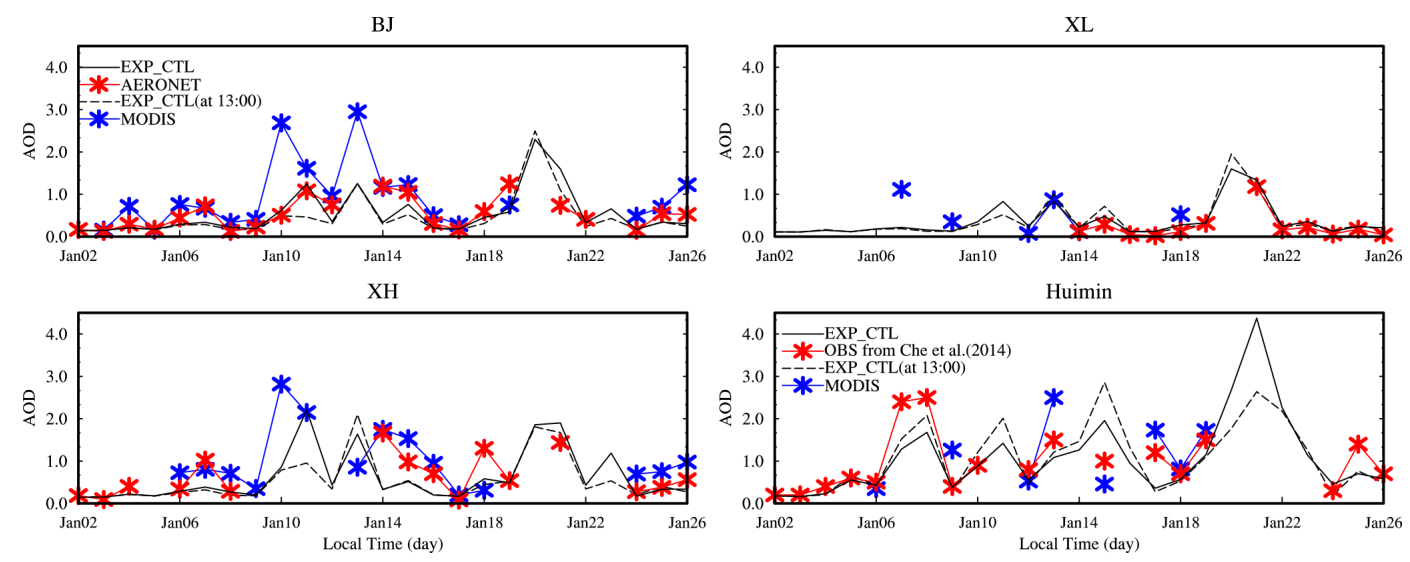

Figure 5. Time series of daily AOD at $550 \mathrm{~nm}$ at BJ, XL, and XH from AERONET measurements and at Huimin site from Che et al. (2014), MODIS retrievals (at 13:00 LT), and the corresponding WRF-Chem simulation (EXP_CTL) for daily average (solid black line) and at 13:00 LT (dash black line) during 2-26 January 2013.

is showed in Fig. 5. Statistical analysis of the comparison between the simulated and observed daily AOD from AERONET is presented in Table 1. As seen in Fig. 5, the model also reasonably reproduces the day-to-day variations of the observed AOD by AERONET and MODIS, although there are several missing data; the $R$ values between the simulated and observed AODs from AERONET are 0.59, 0.99, 0.60 , and 0.74 for the $\mathrm{BJ}, \mathrm{XL}, \mathrm{XH}$, and Huimin, respectively. The AOD from MODIS is much higher than that from AERONET, indicating that the AOD may be overestimated by MODIS. The modeled averaged AOD is higher at $\mathrm{XH}$ and lower at XL, consistent with the surface $\mathrm{PM}_{2.5}$ concentration at these two sites (Fig. 3). Although the model underestimates AOD at Huimin site with the MB of -0.22 , both observation and model results show that the AOD at Huimin site is highest among the four sites. Considering the location of the Huimin site in Fig. 1, this indicates that the model can reproduce the more serious pollution to the south of Beijing.

In addition, in the Supplement, the comparison of AOD from MODIS observations and the corresponding model results shows that model can reproduce the more pollutants over the south part of Hebei and the evolution of AOD values; the comparison of aerosol extinction coefficient from CloudAerosol Lidar and Infrared Pathfinder Satellite Observations (CALIPSO) and the modeled aerosol extinction coefficient shows that the model can also capture the vertical distribution and the evolution of aerosol extinction coefficient during the fog-haze period (10-15 January).

\subsection{Aerosol impacts on surface energy, meteorological variables, and atmospheric stability}

In this section, the aerosol radiative forcing (ARF) and its impacts on surface energy, temperature, $\mathrm{RH}$, atmospheric stability, wind, and PBLH during the fog-haze period (1015 January) with the simulated maximum surface $\mathrm{PM}_{2.5}$ con- centration of $\sim 600 \mathrm{ug} \mathrm{m}^{-3}$, minimum atmospheric visibility of $\sim 0.3 \mathrm{~km}$, and $10-100 \mathrm{~h}$ of simulated hourly surface $\mathrm{PM}_{2.5}$ concentration above $300 \mathrm{ug} \mathrm{m}^{-3}$ over NCP are presented. Beijing, Tianjin, and southern Hebei $\left(36.2-41^{\circ} \mathrm{N}\right.$, $114-118^{\circ} \mathrm{E}$; black box in Fig. 1) is the key high-aerosolconcentration region over the NCP where there may be significant impacts of aerosol on meteorological variables in the atmospheric boundary layer. Figure 6 is the time series of aerosol-induced daily and diurnal change in the surface energy budget (latent heat (LH), sensible heat (SH), shortwave $(\mathrm{SW})$ radiation, long-wave (LW) radiation, and net energy flux $(\mathrm{LH}+\mathrm{LW}+\mathrm{SH}+\mathrm{SW}))$ and meteorological variables (temperature at $2 \mathrm{~m}, \mathrm{RH}$ at $2 \mathrm{~m}$ ) averaged for the $\mathrm{BTH}$ region, which is calculated by subtracting the model results of EXP_NOEF from those of EXP_CTL. The diurnal change is calculated for 10-15 January, the pollution episode. Positive values indicate more energy flux toward the surface or reduced energy flux away from the surface. Figure 6a shows that during 2-26 January, the SW fluxes at the surface are reduced by $8-36 \mathrm{~W} \mathrm{~m}^{-2}$ due to aerosol scattering and absorption of solar radiation at the surface. The SW fluxes are reduced by $25-35 \mathrm{~W} \mathrm{~m}^{-2}$ during $10-15$ January. The LW fluxes are increased slightly by up to $6 \mathrm{~W} \mathrm{~m}^{-2}$ during 2 26 January, with values of $4-6 \mathrm{~W} \mathrm{~m}^{-2}$ during $10-15$ January due to the positive radiative forcing in the atmospheric by aerosol. Because of the cooling effect of aerosol at the surface, the $\mathrm{LH}$ and $\mathrm{SH}$ fluxes from the surface to the atmosphere during 2-26 January are also reduced by $1-5$ and 5$16 \mathrm{~W} \mathrm{~m}^{-2}$, respectively. The net energy fluxes at the surface are reduced by $15-50 \mathrm{~W} \mathrm{~m}^{-2}$, with values of $39-47 \mathrm{~W} \mathrm{~m}^{-2}$ during 10-15 January. Therefore, during the fog-haze period, the energy arriving at the surface was largely reduced. In Fig. 6c, the diurnal change shows the change of surface energy is significant during the daytime: during 10-15 January, at 09:00-18:00, aerosol reduces SW fluxes, LH fluxes, and SH fluxes by $10-105,2-16$, and $9-46 \mathrm{~W} \mathrm{~m}^{-2}$, respec- 

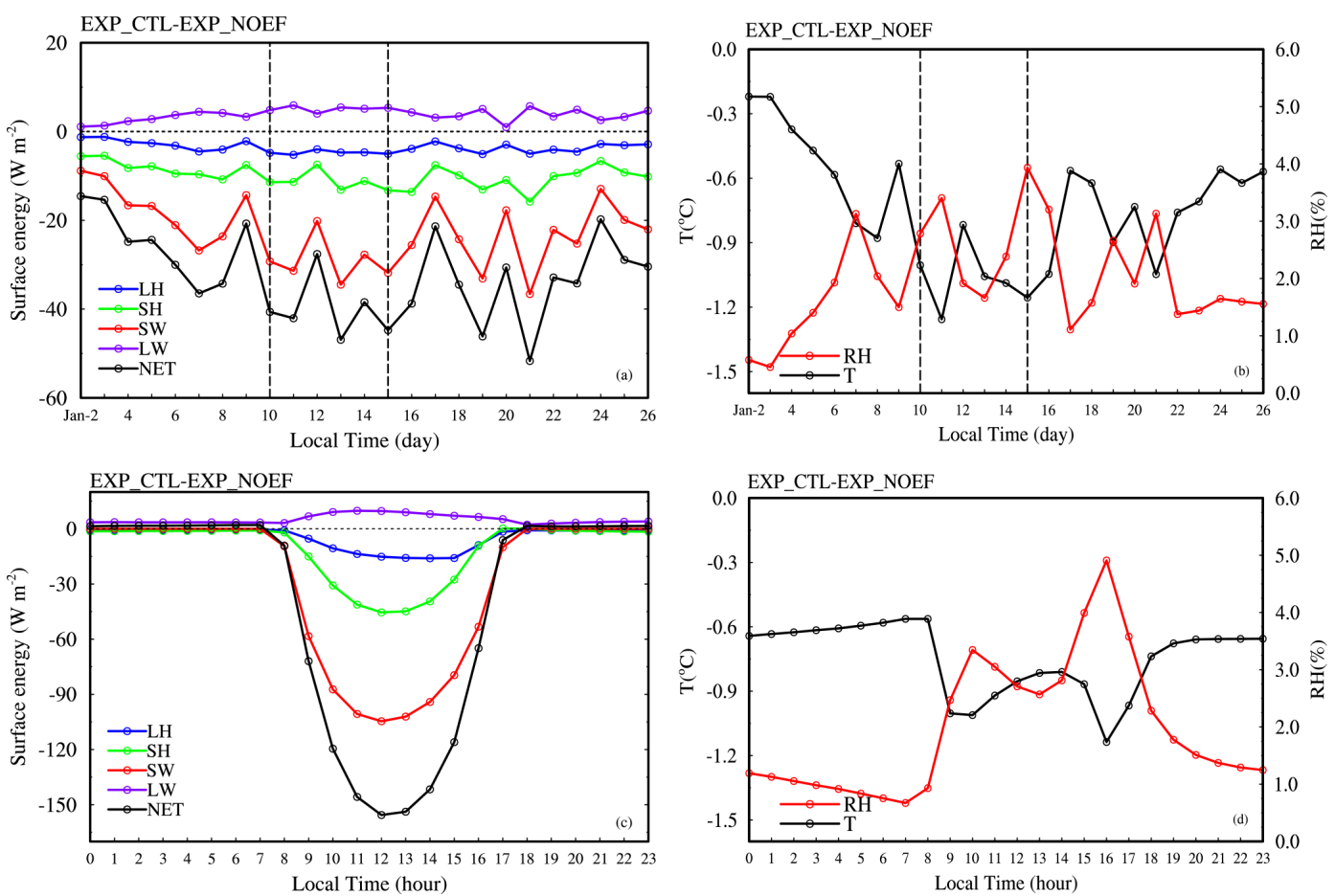

Figure 6. Time series of aerosol-induced daily change in (a) surface energy budget (SH, LH, LW radiation, SW radiation, and net energy flux, $\mathrm{W} \mathrm{m}^{-2}$ ) and (b) meteorological variables $\left(2 \mathrm{~m}\right.$ temperature $\left.\left({ }^{\circ} \mathrm{C}\right), 2 \mathrm{~m} \mathrm{RH}(\%)\right)$ averaged for the $\mathrm{BTH}$ region $\left(36-42^{\circ} \mathrm{N}, 113-120^{\circ} \mathrm{E}\right)$ during 2-26 January. Time series of aerosol-induced diurnal change of (c) surface energy budget and (d) meteorological variables averaged for the BTH region and the period 10-15 January 2013. LH is latent heat, LW is long-wave radiation, SH is sensible heat, SW is shortwave radiation, and NET is the sum of the total energy fluxes.

tively, and increases LW fluxes by $2-10 \mathrm{~W} \mathrm{~m}^{-2}$; during the nighttime, aerosol only increases the LW flux from the atmosphere to the surface by $\sim 3 \mathrm{~W} \mathrm{~m}^{-2}$. The net surface energy decreases by $6-156 \mathrm{~W} \mathrm{~m}^{-2}$ during 09:00-18:00 and increases by a slightly positive value of around $\sim 1.5 \mathrm{~W} \mathrm{~m}^{-2}$ during 00:00-07:00 and 18:00-23:00, which may lead to surface cooling during the daytime.

For the daily variation of aerosol-induced $2 \mathrm{~m}$ temperature and $2 \mathrm{~m} \mathrm{RH}$ (in Fig. 6b), averaged for the BTH region, aerosols induce a reduction of surface temperature by $0.2-$ $1.3^{\circ} \mathrm{C}$ during $2-26$ January, with values of $0.8-1.3^{\circ} \mathrm{C}$ during 10-15 January, the largest reduction during 2-26 January. Aerosols lead to a slight increase of the surface RH by $0.5-$ $4 \%$ during 2-26 January. For the diurnal change depicted in Fig. 6d, it can be seen that the reduction of surface temperature is at a maximum of $0.7-1.1^{\circ} \mathrm{C}$ during 09:00-18:00 but remains at around $0.6^{\circ} \mathrm{C}$ during 00:00-08:00 and 19:0023:00. The aerosol-induced surface $\mathrm{RH}$ increases by $2-5 \%$ during 09:00-18:00 but by only 1-2\% during 00:00-08:00 and 19:00-23:00. In general, the changes in meteorological variables take place mainly during the daytime (09:0018:00).

Figure 7 is the spatial distribution of ARF at the bottom of the atmosphere and in the atmosphere and the aerosol impacts on $2 \mathrm{~m}$ temperature and $2 \mathrm{~m} \mathrm{RH}$, calculated by sub- tracting the model results of EXP_NOEF from those of EXP_CTL averaged during 09:00-18:00, 10-15 January. From Fig. 7a, the ARF at the bottom is highest over south Hebei and Tianjin, with values of -80 to $-140 \mathrm{~W} \mathrm{~m}^{-2}$, and ranges from -60 to $-100 \mathrm{~W} \mathrm{~m}^{-2}$ over south Beijing. Che et al. (2014) analyzed observations at several sites over the NCP during January 2013 and indicated that the daily ARF during $10-15$ January at the surface was about -50 to $-75 \mathrm{~W} \mathrm{~m}^{-2}$ over north Beijing and about -100 to $-150 \mathrm{~W} \mathrm{~m}^{-2}$ over south Beijing and Hebei. These results are to some extent consistent with the model results in Fig. 7a. Contrary to the significant negative ARF at the bottom, the ARF in the atmosphere in Fig. $7 b$ shows that there is a large, positive ARF with the value of 40 to $120 \mathrm{~W} \mathrm{~m}^{-2}$ over south Hebei and Tianjin and 20 to $80 \mathrm{~W} \mathrm{~m}^{-2}$ over south Beijing. Therefore, a more stable atmosphere is expected. In Fig. 7c, the aerosolinduced surface temperature decreases most over Tianjin and south Hebei, with values of -1.6 to $-2.8^{\circ} \mathrm{C}$. The temperature also decreases by about 0.4 to $1.6^{\circ} \mathrm{C}$ over Beijing and other parts of Hebei. Such a reduction of temperature is a reflection of the decrease in solar radiation reaching the earth's surface due to aerosols. In Fig. 7c, the aerosol-induced surface RH increases by about 8-14\% over south Hebei, by 4 $6 \%$ over Tianjin, and by $2-4 \%$ over Beijing. As the aerosolinduced change in water vapor mixing ratio is very small (1- 
(a)ARF at BOT( $\left(\mathrm{W} \mathrm{m}^{-2}\right)$

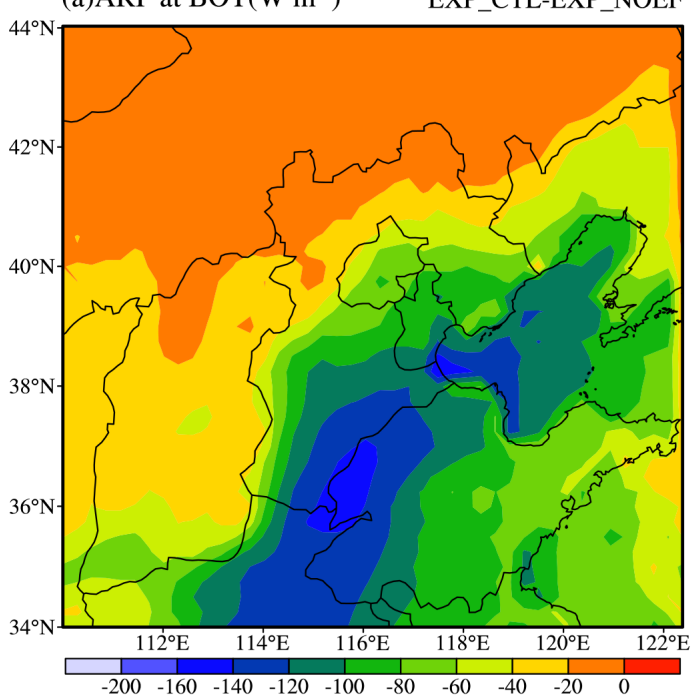

(c) $\mathrm{T}\left({ }^{\circ} \mathrm{C}\right)$

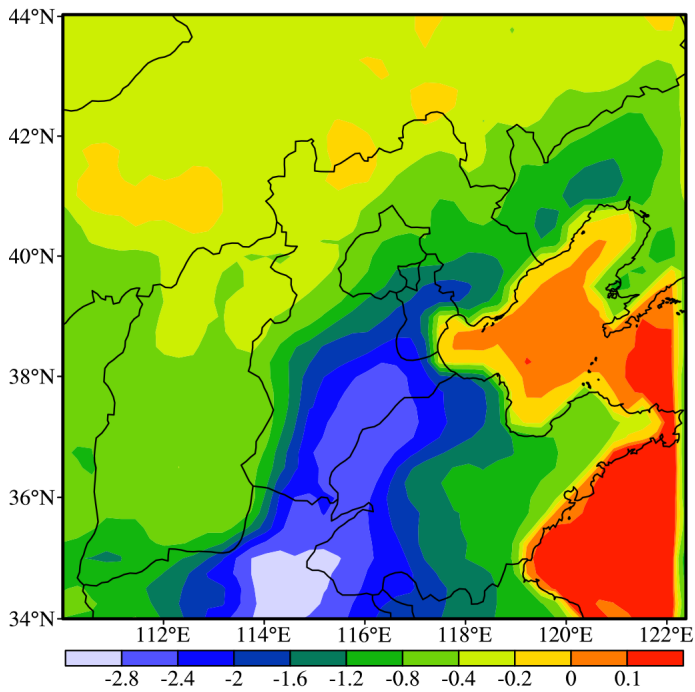

(b)ARF in $\mathrm{ATM}\left(\mathrm{W} \mathrm{m}^{-2}\right)$

EXP_CTL-EXP_NOEF

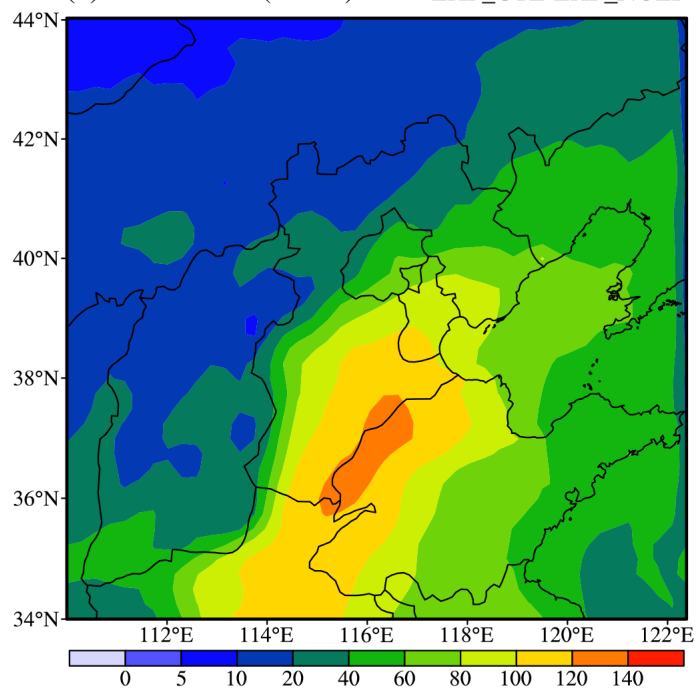

(d) $\mathrm{RH}(\%)$

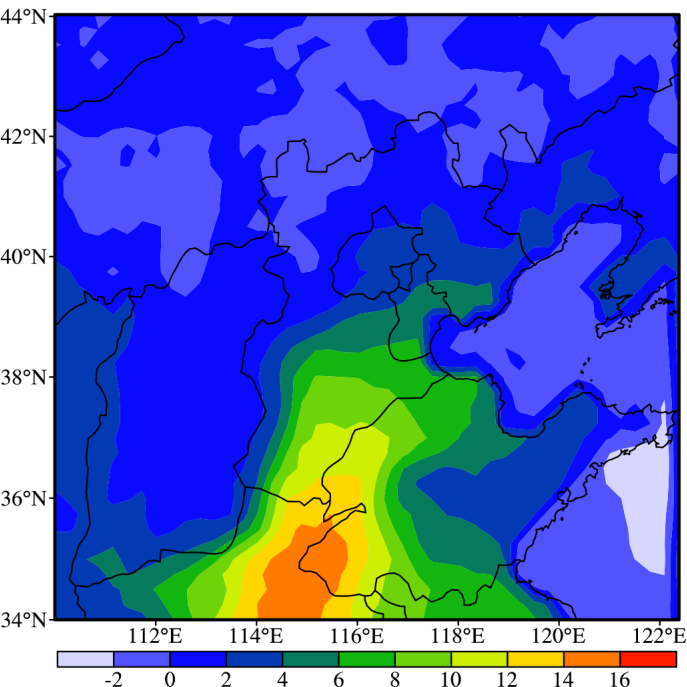

Figure 7. Spatial distribution of aerosol radiative forcing $\left(\mathrm{ARF}, \mathrm{W} \mathrm{m}^{-2}\right)$ (a) at bottom and (b) in the atmosphere and the aerosol-induced change in (c) $2 \mathrm{~m}$ temperature $\left({ }^{\circ} \mathrm{C}\right)$ and (d) $2 \mathrm{~m} \mathrm{RH}(\%)$ averaged over 09:00-18:00 during 10-15 January 2013.

$2 \%$ ) over the NCP area (figure not shown), the decrease in temperature can lead to a decrease in the saturation pressure of water vapor and an increase in RH at the surface, which is beneficial for the hygroscopic growth of aerosols. Figure 8 is the time-altitude distribution of the diurnal cycle of aerosol impacts on temperature and $\mathrm{RH}$ averaged for the $\mathrm{BTH}$ region during 10-15 January. In Fig. 8a it can be seen that, consistent with Fig. 7a, the temperature decreases near the surface (under $950 \mathrm{hPa}$ ), with the highest reduction $\left(0.5-1.5^{\circ} \mathrm{C}\right)$ during 09:00-18:00, while it increases by $0.1-0.5^{\circ} \mathrm{C}$ between 950 and $850 \mathrm{hPa}$ during 11:00-16:00. Such a change in temperature can increase the stability of the atmosphere during daytime. For RH (Fig. 8b), similar to the change at the surface, its change is opposite to the change in temperature, in- creasing by about 2-4\% under $950 \mathrm{hPa}$ and decreasing by about 1-6\% between 950 and $850 \mathrm{hPa}$ during 09:00-20:00.

From the above discussion, the aerosol-induced change of the solar radiation and meteorological variables may change the stability of the atmosphere during the fog-haze event. The profile of the EPT can be used to characterize the stability of the atmosphere. Figure 9 is the aerosol impact on EPT profiles at 00:00, 06:00, 12:00, and 18:00, averaged during 10-15 January in the BTH region. As seen in Fig. 9, the impact of aerosol on EPT does not change too much with altitude at 00:00 and 06:00: the EPT decreases by up to around $0.7 \mathrm{~K}$ under $950 \mathrm{hPa}$. At 12:00, aerosol decreases the EPT near the surface (under $925 \mathrm{hPa}$ ) by up to around $1.3 \mathrm{~K}$ and increases it between 925 and $750 \mathrm{hPa}$ by up to $0.12 \mathrm{~K}$. This suggests that, at 12:00, aerosol leads to a more stable atmo- 

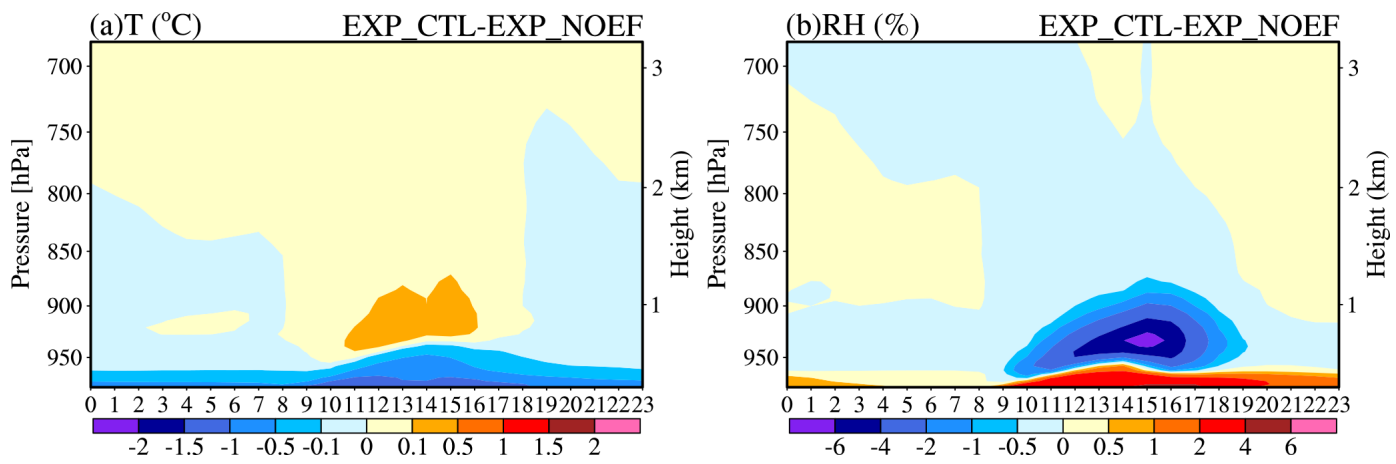

Figure 8. Time-altitude distribution of aerosol-induced diurnal change in (a) temperature $\left({ }^{\circ} \mathrm{C}\right)$ and $(\mathbf{b}) \mathrm{RH}(\%)$ averaged for the BTH region and the period 10-15 January 2013.

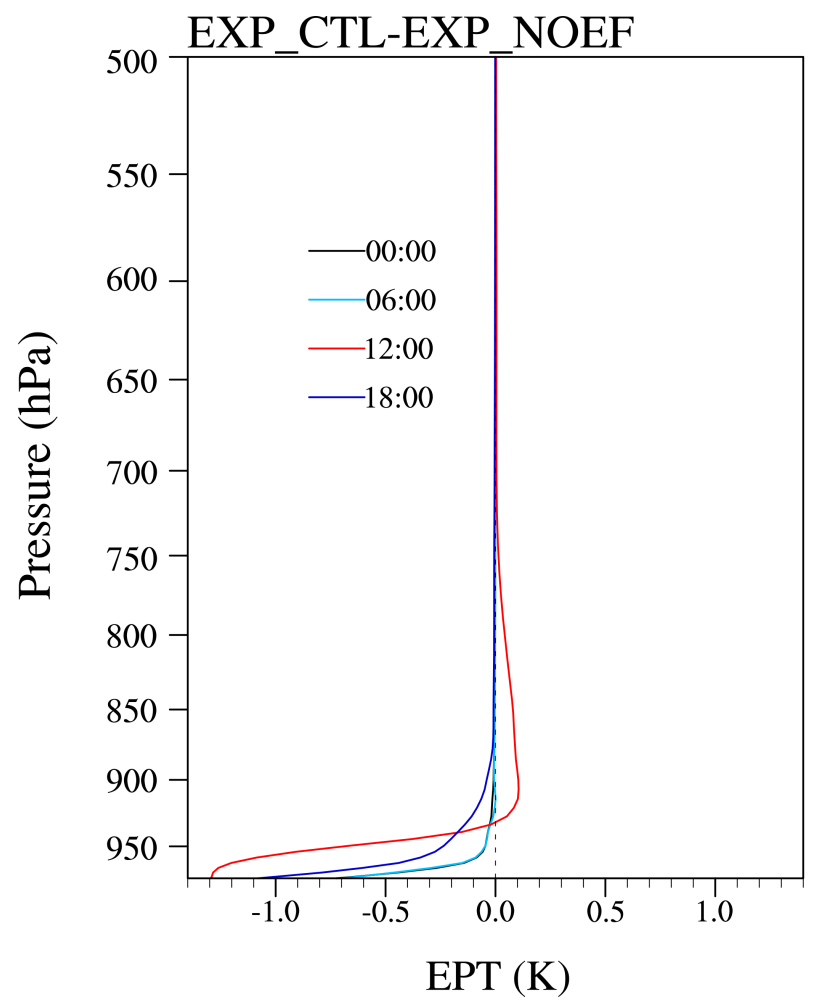

Figure 9. Aerosol impact on equivalent potential temperature (EPT, K) profiles at 00:00, 06:00, 12:00, and 18:00 averaged for the BTH region and the period 10-15 January 2013.

sphere. Aerosol decreases EPT by up to around $1.1 \mathrm{~K}$ under $875 \mathrm{hPa}$ at 18:00.

As a results of the more stable atmosphere, Fig. 10 shows the diurnal variation of surface $\mathrm{PM}_{2.5}$ concentration from EXP_CTL and aerosol-induced $10 \mathrm{~m}$ wind speed and PBLH change. In Fig. 10, averaged for the BTH region, the aerosolinduced surface wind speed decreases during 09:00-18:00, with values of $0.1-0.34 \mathrm{~m} \mathrm{~s}^{-1}(3-10 \%)$, while there is no change at other times of the night. The maximum decrease of wind speed is during 14:00-16:00. The decrease of surface

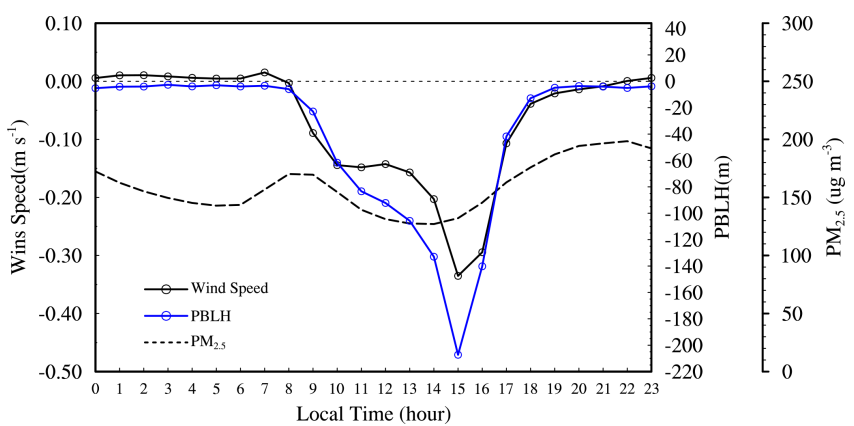

Figure 10. Time series of diurnal variation of surface $\mathrm{PM}_{2.5}$ concentration from EXP_CTL and aerosol-induced diurnal change of wind speed $\left(\mathrm{m} \mathrm{s}^{-1}\right)$ and PBLH $(\mathrm{m})$ averaged for the BTH region and the period 10-15 January 2013.

wind speed is not favorable for the diffusion of air pollutants. The PBLH decreases by 22-207 $\mathrm{m}(8-32 \%)$ during 09:0017:00, with the maximum reduction (17-32\%) seen during 13:00-16:00. The large decrease of PBLH is beneficial for the accumulation of the air pollutant. It is noticed that the surface $\mathrm{PM}_{2.5}$ concentration is lowest during 11:00-16:00. This indicates that the changed meteorological condition will have the largest impacts on the lowest $\mathrm{PM}_{2.5}$ concentration.

\subsection{Feedback of aerosol-induced meteorological variables changes to aerosol concentration}

The above changes in meteorological variables as a result of aerosol effects (e.g., the decrease of temperature at the surface and the increase of temperature in the middle atmosphere, the increase of RH at the surface and in the lower atmosphere, the more stable atmosphere and the decrease in wind speed and PBLH) can have impacts on the surface $\mathrm{PM}_{2.5}$ concentration and eventually contribute to the maintenance and deterioration of regional air pollution. Figure 11a, $\mathrm{c}$, and e show the hourly surface $\mathrm{PM}_{2.5}$ concentration from EXP_NOEF and the impacts of changes in meteorological variables on hourly surface $\mathrm{PM}_{2.5}$ concentration averaged 
(a)Beijing

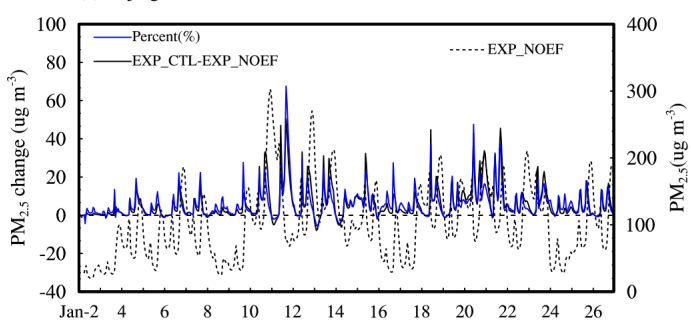

(c)Tianjin

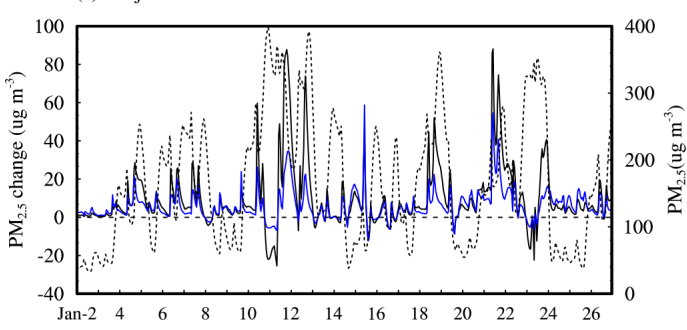

(e)Hebei

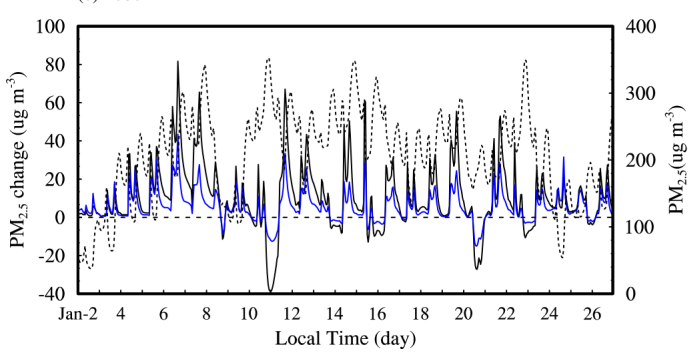

(b)Beijing

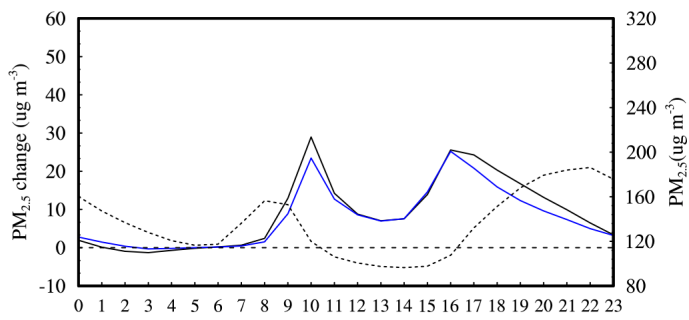

(d)Tianjin

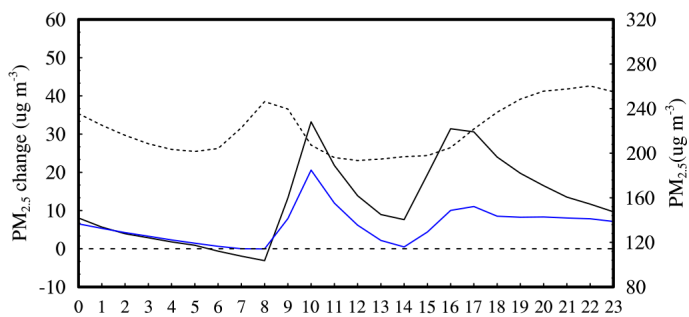

(f)Hebei

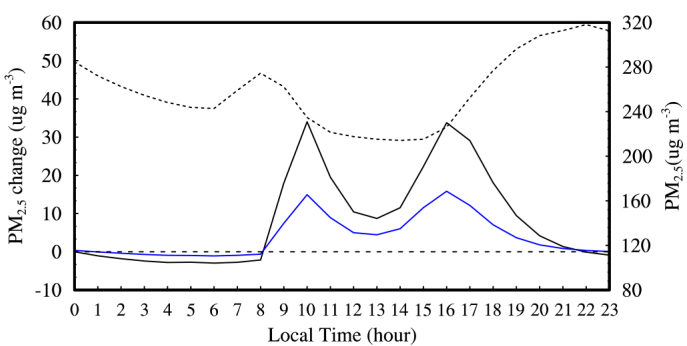

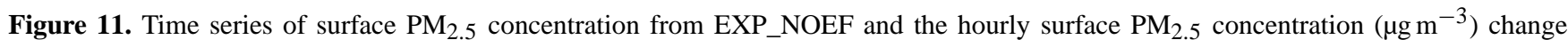
induced by meteorological variable change averaged for (a) Beijing, (c) Tianjin, and (e) Hebei during 2-26 January and the corresponding diurnal change averaged for (b) Beijing, (d) Tianjin, and (f) Hebei during 10-15 January 2013. The black solid line denotes the change value of surface $\mathrm{PM}_{2.5}$ concentration and the blue solid line denotes the corresponding change in percentage terms compared to the surface $\mathrm{PM}_{2.5}$ concentration from the model results of EXP_NOEF. Beijing, Tianjin, and Hebei comprise the BTH region (dashed blue boxes in Fig. 1).

for the three sub-regions of the BTH during 2-26 January. The corresponding diurnal change during 10-15 January are shown in Fig. 11b, $d$, and $f$. The change in percentage is calculated by comparing with the surface $\mathrm{PM}_{2.5}$ concentration from EXP_NOEF. Among the three sub-regions of the BTH, surface $\mathrm{PM}_{2.5}$ concentration is highest over Hebei. It can be seen that the maximum increase of surface $\mathrm{PM}_{2.5}$ concentration induced by meteorological variable change is around 50 (70\%), $90(60 \%)$, and $80 \mu \mathrm{g} \mathrm{m}^{-3}(40 \%)$ for Beijing, Tianjin, and Hebei, respectively, during 10-15 January. For the average differences among Beijing, Tianjin, and Hebei, the higher the surface $\mathrm{PM}_{2.5}$ concentration is, the greater the increase is in the surface $\mathrm{PM}_{2.5}$ concentration produced by unfavorable meteorological conditions. Note that the time when the maximum increase in surface $\mathrm{PM}_{2.5}$ concentration occurs is not the time when the maximum surface $\mathrm{PM}_{2.5}$ concentration occurs. Averaged during 10-15 January, the diurnal changes in surface $\mathrm{PM}_{2.5}$ concentration in Fig. $11 \mathrm{~b}, \mathrm{~d}$, and $\mathrm{f}$ show that the increase in surface $\mathrm{PM}_{2.5}$ concentration starts from 09:00, with values of 6-28 (10-25\%), 10-35 (7-20\%), and $10-35 \mu \mathrm{g} \mathrm{m}^{-3}(7-15 \%)$ for Beijing, Tianjin, and Hebei, respectively. The surface $\mathrm{PM}_{2.5}$ concentration is maximum at around 08:00 and 20:00 and minimum during 10:00-16:00, while the maximum increase in surface $\mathrm{PM}_{2.5}$ concentration occurs at 10:00 and 16:00. The feedback of meteorological variables change to surface $\mathrm{PM}_{2.5}$ concentration is significant during 09:00-18:00 and thus increases the average value and weakens the daily variation of surface $\mathrm{PM}_{2.5}$ concentration.

Figure 12a shows the impact of changes in meteorological variables on the spatial distribution of surface $\mathrm{PM}_{2.5}$ concentration averaged during 09:00-18:00, 10-15 January. Consistent with Fig. 11, the increase of surface $\mathrm{PM}_{2.5}$ concentration induced by meteorological variable change is maximum over Tianjin and south Hebei, with values of $30-50 \mu \mathrm{g} \mathrm{m}^{-3}$; in south Beijing, the values range from 10 to $40 \mathrm{\mu g} \mathrm{m}^{-3}$. Figure $12 \mathrm{~b}$ shows that the corresponding surface $\mathrm{PM}_{2.5}$ concentration change in percentage terms is higher over southeast Beijing and north Tianjin with the value of $15-30 \%$ while is $2-15 \%$ over south Hebei, south Tianjin, and north Beijing. It can be concluded that aerosol induces a more stable atmosphere, which is favorable for the accumulation of air pollutants, and thus contributes to the formation of fog- 

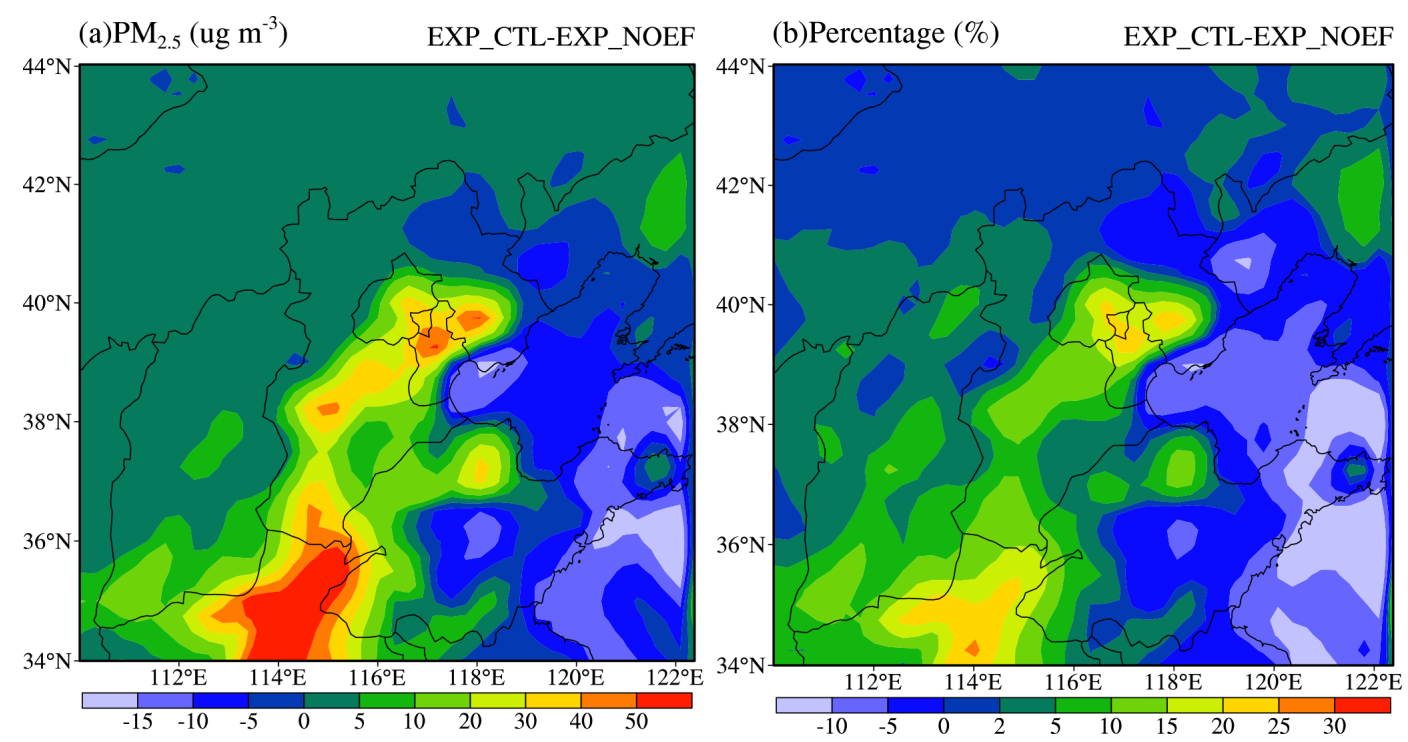

Figure 12. (a) Spatial distribution of the surface $\mathrm{PM}_{2.5}$ concentration change $\left(\mu \mathrm{g} \mathrm{m}^{-3}\right)$ induced by meteorological variable change averaged over 09:00-18:00 during 10-15 January 2013. Panel (b) shows the change in percentage terms compared to the surface $\mathrm{PM}_{2.5}$ concentration from the model results of EXP_NOEF.

haze events. A mechanism of positive feedback exists between aerosol concentration and aerosol-induced meteorological conditions.

\section{Conclusions}

Heavy particulate pollution and fog-haze events over the NCP have drawn much attention recently. In this paper, we estimate the feedback between atmospheric aerosols and meteorological variables during a fog-haze period in January 2013. This is achieved by conducting numerical simulations using the coupled meteorology and aerosol/chemistry model WRF-Chem. The period from 10 to 15 January, when the NCP experienced a severe fog-haze event, is analyzed in detail. Major conclusions are as follows.

The spatial and temporal characteristics of temperature, RH, wind, surface $\mathrm{PM}_{2.5}$ concentration, visibility, and AOD during 2-26 January 2013 is reproduced by the simulation using the fully coupled WRF-Chem model.

The results of the numerical experiments show that, averaged during 09:00-18:00, 10-15 January, aerosols lead to a significant negative radiative forcing of $-20--140 \mathrm{~W} \mathrm{~m}^{-2}$ at the surface and a large positive radiative forcing of 20 $120 \mathrm{~W} \mathrm{~m}^{-2}$ in the atmosphere, the temperature decreases by $0.8-2.8^{\circ} \mathrm{C}$ at the surface and increases by $0.1-0.5^{\circ} \mathrm{C}$ at around $925 \mathrm{hPa}$, and the RH increases by about $4-12 \%$ at the surface and decreases by $1-6 \%$ at around $925 \mathrm{hPa}$. The maximum change occurs over urban Beijing and Tianjin and south Hebei. As a result, the aerosol-induced equivalent potential temperature profile change shows that the atmosphere is much more stable, and thus the surface wind speed de- creases by up to $0.3 \mathrm{~m} \mathrm{~s}^{-1}(10 \%)$ and the atmosphere boundary layer height decreases by 40-200 $\mathrm{m} \mathrm{(5-30 \% )} \mathrm{during} \mathrm{the}$ daytime of this severe fog-haze event.

The results of the numerical experiments also show that, due to such a more stable atmosphere, compared to the surface $\mathrm{PM}_{2.5}$ concentration from the model results without aerosol feedback, the maximum increase of hourly surface $\mathrm{PM}_{2.5}$ concentration is around $50(70 \%), 90(60 \%)$, and $80 \mu \mathrm{g} \mathrm{m}^{-3}(40 \%)$ in Beijing, Tianjin, and south Hebei, respectively, during 10-15 January. The surface $\mathrm{PM}_{2.5}$ concentration averaged during 09:00-18:00, 10-15 January, over the NCP, increases by $10-50 \mu \mathrm{g} \mathrm{m}^{-3}$, with the maximum change taking place over urban Beijing and Tianjin and south Hebei. Although the aerosol concentration is maximum during the nighttime, the feedback mechanism by which meteorological variables increase the aerosol concentration most occurs during daytime (at around 10:00 and 16:00 LT). These results suggest that aerosol induces a more stable atmosphere, which is favorable for the accumulation of air pollutants, and thus contributes to the formation of fog-haze events. A mechanism of positive feedback exists between aerosol concentration and aerosol-induced meteorological conditions.

There are uncertainties in this study. The model overestimates $\mathrm{PM}_{2.5}$ at Xianghe and Tianjin according to Fig. 3. The diurnal variation of $\mathrm{PM}_{2.5}$ at Xianghe and Tianjin from model results and observations shows that the overestimation is basically at night, which may relate to the model's setting of the atmospheric boundary layer height and also the bias of emission inputted to the model. As the aerosol feedback derived from the aerosol radiative effect mainly has large impacts during daytime, it is noted that the overestimation of 
$\mathrm{PM}_{2.5}$ may lead to slight overestimation of the aerosol feedback during the pollutant period. Emission with higher resolution may be useful for improving the model performance. The aerosol direct and indirect effect is also very sensitive to the mixing state between scattering aerosols and absorbing aerosols. Moreover, the feedback between aerosol and cloud/meteorological parameters also has large uncertainty. Although aerosol indirect forcing is considered in WRFChem, it only includes the aerosol effect on resolved stratiform clouds. With a horizontal resolution of $27 \mathrm{~km}$, convective clouds are still parameterized in the model without explicit cloud microphysics in the convective cloud parameterization that links aerosols to cloud condensation or ice nuclei.

\section{The Supplement related to this article is available online at doi:10.5194/acp-15-4279-2015-supplement.}

Acknowledgements. This work was supported by the National Basic Research Program of China (2014CB953802), the "Strategic Priority Research Program (B)" of the Chinese Academy of Sciences (XDB05030105, XDB05030102, XDB05030103), the International S\&T Cooperation Program of China (2011DFG23450), the National Natural Science Foundation of China (41305010), and the Russian Scientific Fund under grant 14-47-00049.

Edited by: L. Zhang

\section{References}

Abdul-Razzak, H. and Ghan, S. J.: A parameterization of aerosol activation 2. Multiple aerosol types, J. Geophys. Res., 105, 68376844, 2000.

Albrecht, B. A.: Aerosols, cloud microphysics, and fractional cloudiness, Science, 245, 1227-1230, 1989.

Barnard, J. C., Fast, J. D., Paredes-Miranda, G., Arnott, W. P., and Laskin, A.: Technical Note: Evaluation of the WRF-Chem "Aerosol Chemical to Aerosol Optical Properties" Module using data from the MILAGRO campaign, Atmos. Chem. Phys., 10, 7325-7340, doi:10.5194/acp-10-7325-2010, 2010.

Brown, J. F., Loveland, T. R., Merchant, J. W., Reed, B. C., and Ohlen, D. O.: Using multi-source data in global land-cover characterization: concepts, requirements, and methods, Photogram. Eng. Rem. S., 59, 977-987, 1993.

Chan, C. K. and Yao, X.: Air pollution in mega cities in China, Atmos. Environ., 42, 1-42, 2008.

Che, H., Zhang, X., Li, Y., Zhou, Z., and Qu, J. J.: Horizontal visibility trends in China 1981-2005, Geophys. Res. Lett., 34, L24706, doi:10.1029/2007GL031450, 2007.

Che, H., Zhang, X., Chen, H., Damiri, B., Goloub, P., Li, Z., Zhang, X.,Wei, Y., Zhou, H., Dong, F., Li, D., and Zhou, T.: Instrument calibration and aerosol optical depth validation of the China Aerosol Remote Sensing Network, J. Geophys. Res., 114, D03206, doi:10.1029/2008JD011030, 2009a.
Che, H., Zhang, X., Li, Y., Zhou, Z., Qu, J., and Hao, X.: Haze trends over the capital cities of 31 provinces in China, 19812005, Theor. Appl. Climatol., 97, 235-242, 2009 b.

Che, H., Xia, X., Zhu, J., Li, Z., Dubovik, O., Holben, B., Goloub, P., Chen, H., Estelles, V., Cuevas-Agulló, E., Blarel, L., Wang, H., Zhao, H., Zhang, X., Wang, Y., Sun, J., Tao, R., Zhang, X., and Shi, G.: Column aerosol optical properties and aerosol radiative forcing during a serious haze-fog month over North China Plain in 2013 based on ground-based sunphotometer measurements, Atmos. Chem. Phys., 14, 2125-2138, doi:10.5194/acp14-2125-2014, 2014.

Cheng, S., Yang, L., Zhou, X., Xue, L., Gao, X., Zhou, Y., and Wang, W.: Size-fractionated water-soluble ions, situ PH and water content in aerosol on hazy days and the influences on visibility impairment in Jinan, China, Atmos. Environ., 45, 4631-4640, 2011.

Deng, X. J., Tie, X., Wu, D., Zhou, X. J., Tan, H. B., Li, F., and Jiang, C.: Long-term trend of visibility and its characterizations in the Pearl River Delta Region (PRD), China, Atmos. Environ., 42, 1424-1435, 2008.

Dubovik, O. and King, M. D.: A flexible inversion algorithm for retrieval of aerosol optical properties from Sun and sky radiance measurements, J. Geophys. Res., 105, 20673-20696, 2000.

Dubovik, O., Holben, B., Eck, T. F., Smirnov, A., Kaufman, Y. J., King, M. D., Tanre, D., and Slutsker, I.: Variability of absorption and optical properties of key aerosol types observed in worldwide locations, J. Atmos. Sci., 59, 590-608, 2002.

Fast, J. D., Gustafson Jr., W. I., Easter, R. C., Zaveri, R. A., Barnard, J. C., Chapman, E. G., and Grell, G. A.: Evolution of ozone, particulates, and aerosol direct forcing in an urban area using anew fully-coupled meteorology, chemistry, and aerosol model, J. Geophys. Res., 111, D21305, doi:10.1029/2005JD006721, 2006.

Feng, S., Hu, S. Q., and Qian, W. H.: Quality control of daily meteorological data in China, 1951-2000: A new dataset, Int. J. Climatol., 24, 853-870, 2004.

Gao, Y. and Zhang, M.: Numerical simulation of a heavy fog-haze episode over the North China Plain in January 2013, Clim. Environ. Res., 19, 140-152, 2014 (in Chinese).

Ghan, S. J., Easter, R. C., Hudson, J., and Breon, F.-M.: Evaluation of Aerosol Indirect Radiative Forcing in MIRAGE, J. Geophys. Res., 106, 5317-5334, 2001a.

Ghan, S., Laulainen, N., Easter, R., Wagener, R., Nemesure, S., Chapman, E., Zhang, Y., and Leung, R.: Evaluation of aerosol direct radiative forcing in MIRAGE, J. Geophys. Res., 106, 52955316, 2001b.

Gong, S. L.: A parameterization of sea-salt aerosol source function for sub- and super-micron particles, Global Biogeochem. Cy., 17, 1097, doi:10.1029/2003GB002079, 2003.

Gong, S. L., Barrie, L. A., and Blanchet, J.-P.: Modeling sea-salt aerosols in the atmosphere, J. Geophys. Res., 102, 3805-3818, 1997.

Grell, G. A., Peckham, S. E., Schmitz, R., McKeen, S. A., Frost, G., Skamarock, W. C., and Eder, B.: Fully coupled "online" chemistry within the WRF model, Atmos. Environ., 39, 6957-6975, 2005.

Guenther, A., Karl, T., Harley, P., Wiedinmyer, C., Palmer, P. I., and Geron, C.: Estimates of global terrestrial isoprene emissions using MEGAN (Model of Emissions of Gases and Aerosols from 
Nature), Atmos. Chem. Phys., 6, 3181-3210, doi:10.5194/acp-63181-2006, 2006.

Gustafson Jr., W. I., Chapman, E. G., Ghan, S. J., Easter, R. C., and Fast, J. D.: Impact on modeled cloud characteristics due to simplified treatment of uniform cloud condensation nuclei during NEAQS 2004, Geophys. Res. Lett., 34, L19809, doi:10.1029/2007GL030021, 2007.

Han, X., Zhang, M., Tao, J., Wang, L., Gao, J., Wang, S., and Chai, F.: Modeling aerosol impacts on atmospheric visibility in Beijing with RAMS-CMAQ, Atmos. Environ., 72, 177-191, 2013.

He, K. B.: Multi-resolution Emission Inventory for China (MEIC): model framework and 1990-2010 anthropogenic emissions, International Global Atmospheric Chemistry Conference, 17-21 September, Beijing, China, 2012.

Holben, B. N., Eck, T. F., Slutsker, I., Tanre, D., Buis, J. P., Setzer, A., Vermote, E., Reagan, J. A., Kaufman, Y. J., Nakajima, T., Lavenu, F., Jankowiak, I., and Smirnov, A.: AERONET-A federated instrument network and data archive for aerosol characterization, Remote Sens. Environ., 66, 1-16, 1998.

Hsu, N. C., Jeong, M. J., Bettenhausen, C., Sayer, A. M., Hansell, R., Seftor, C. S., Huang, J., and Tsay, S. C.: Enhanced Deep Blue aerosol retrieval algorithm: The second generation, J. Geophys. Res., 118, 9296-9315, 2013.

Huang, Y., Dickinson, R. E., and Chameides, W. L.: Impact of aerosol indirect effect on surface temperature over East Asia, Proc. Natl. Acad. Sci., 103, 4371-4376, 2006.

Jaeglé, L., Quinn, P. K., Bates, T. S., Alexander, B., and Lin, J.-T.: Global distribution of sea salt aerosols: new constraints from in situ and remote sensing observations, Atmos. Chem. Phys., 11, 3137-3157, doi:10.5194/acp-11-3137-2011, 2011.

Lei, Y., Zhang, Q., He, K .B., and Streets, D. G.: Primary anthropogenic aerosol emission trends for China, 1990-2005, Atmos. Chem. Phys., 11, 931-954, doi:10.5194/acp-11-931-2011, 2011.

Li, Z., Xia, X., Cribb, M., Mi, W., Holben, B., Chen, H., Wang, P., Tsay, S.-C., Eck, T. F., Zhao, F., Dutton, E. G., and Dickerson, R. E.: Aerosol optical properties and its radiative effects in northern China, J. Geophys. Res., 112, D22S01, doi:10.1029/2006JD007382, 2007.

Liu, H., Zhang, L., and Wu, J.: A Modeling Study of the Climate Effects of Sulfate and Carbonaceous Aerosols over China, Adv. Atmos. Sci., 27, 1276-1288, 2010.

Liu, J., Xia, X., Wang, P., Li, Z., Zheng, Y., Cribb, M., and Chen, H.: Significant aerosol direct radiative effects during a pollution episode in northern China, Geophys. Res. Lett., 34, L23808, doi:10.1029/2007GL030953, 2007.

Liu, Y., Daum, P. H., and McGraw, R.: Size Truncation Effect, Threshold Behavior, and a New Type of Autoconversion Parameterization, Geophys. Res. Lett., 32, L11811, doi:10.1029/2005GL022636, 2005.

Loveland, T. R., Merchant, J. W., Ohlen, D. O., and Brown, J. F.: Development of a land-cover characteristics database for the conterminous US, Photogram. Eng. Rem. S., 57, 1453-1463, 1991.

Patashnick, H. and Rupprecht, E.: Continuous PM10 measurements using the tapered element oscillating microbalance, J. Air Waste. Manage., 41, 1079-1083, 1991.

Petters, M. D. and Kreidenweis, S. M.: A single parameter representation of hygroscopic growth and cloud condensation nucleus activity, Atmos. Chem. Phys., 7, 1961-1971, doi:10.5194/acp-71961-2007, 2007.
Qian, Y., Leung, L. R., Ghan, S. J., and Giorgi, F.: Regional climate effects of aerosols over China: Modeling and observation, Tellus B, 5I5, 914-934, 2003.

Quan, J., Zhang, Q., He, H., Liu, J., Huang, M., and Jin, H.: Analysis of the formation of fog and haze in North China Plain (NCP), Atmos. Chem. Phys., 11, 8205-8214, doi:10.5194/acp-11-82052011, 2011.

Ramanathan, V., Crutzen, P. J., Kiehl, J. T., and Rosenfeld, D.: Aerosols, climate, and the hydrological cycle, Science, 294, 2119-2124, 2001.

Randerson, J. T., Van der Werf, G. R., Giglio, L., Collatz, G. J., and Kasibhatla, P. S.: Global Fire Emissions Database, Version 2 (GFEDv2.1), available at: http://daac.ornl.gov/ (last access: 11 November 2013), from Oak Ridge National Laboratory Distributed Active Archive Center, Oak Ridge, Tennesse, USA, doi:10.3334/ORNLDAAC/849, 2005.

Skamarock, W. C., Klemp, J. B., Dudhia, J., Gill, D. O., Barker, D. M., Duda, M., Huang, X.-Y., Wang, W., and Powers, J. G.: A description of the Advanced Research WRF version 3, Tech. Rep. NCAR/TN-475+STR, Boulder, Colorado, USA, 113 pp., 2008.

Streets, D. G., Bond, T. C., Carmichael, G. R., Fernandes, S. D., Fu, Q., He, D., Klimont, Z., Nelson, S. M., Tsai, N. Y., Wang, M. Q., Woo, J.-H., and Yarber, K. F.: An inventory of gaseous and primary aerosol emissions in Asia in the year 2000, J. Geophys. Res., 108, 8809, doi:10.1029/2002JD003093, 2003.

Sun, Y., Zhuang, G., Tang, A., Wang, Y., and An, Z.: Chemical characteristics of PM2.5 and PM10 in Haze-Fog episodes in Beijing, Environ. Sci. Technol., 40, 3148-3155, 2006.

Sun, Y., Jiang, Q., Wang, Z., Fu, P., Li, J., Yang, T., and Yin, Y.: Investigation of the Sources and Evolution Processes of Severe Haze Pollution in Beijing in January 2013, J. Geophys. Res. 114, 4380-4398, 2014.

Tao, M., Chen, L., Xiong, X., Zhang, M., Ma, P., Tao, J., and Wang, Z.: Formation process of the widespread extreme haze pollution over northern China in January 2013: implications for regional air quality and climate, Atmos. Environ., 98, 417-425, doi:10.1016/j.atmosenv.2014.09.026, 2014.

Twomey, S.: Pollution and the planetary albedo, Atmos. Environ., 8, 1251-1256, 1974.

Wang, H., Tan, S. C., Wang, Y., Jiang, C., Shi, G. Y., Zhang, M. X., and Che, H. Z.: A multisource observation study of the severe prolonged regional haze episode over eastern China in January 2013, Atmos. Environ., 89, 807-815, 2014.

Wang, S., Zhao, M., Xing, J., Wu, Y., Zhou, Y., Lei, Y., He, K., Fu, L., and Hao, J.: Quantifying the air pollutants emission reduction during the 2008 Olympic games in Beijing, Environ. Sci. Technol., 44, 2490-2496, 2010.

Wang, Y. S., Yao, L., Wang, L. L., Liu, Z., Ji, D., Tang, G., Zhang, J., Sun, Y., Hu, B., and Xin, J.: Mechanism for the formation of the January 2013 heavy haze pollution episode over central and eastern China, Sci. China Earth Sci., 57, 14-25, 2014.

Wu, J., Fu, C., Xu, Y., Tang, J., Han, Z. and Zhang, R.: Effects of total aerosol on temperature and precipitation in East Asia, Clim. Res., 40, 75-87, 2009.

Wu, P. and Han, Z.: Indirect radiative and climatic effects of sulfate and organic carbon aerosols over East Asia investigated by RIEMS, Atmos. Oc. Sci. Lett., 4, 7-11, 2011. 
Xia, X., Li, Z., Wang, P., Chen, H., and Cribb, M.: Estimation of aerosol effects on surface irradiance based on measurements and radiative transfer model simulations in northern China, J. Geophys. Res., 112, D22S10, doi:10.1029/2006JD008337, 2007.

Yu, M., Carmichael, G. R., Zhu, T., and Cheng Y. F.: Sensitivity of predicted pollutant levels to urbanization in China, Atmos. Environ., 60, 544-554, 2012.

Zaveri, R. A., Easter, R. C., Fast, J. D., and Peters, L. K.: Model for simulating aerosol interactions and chemistry (MOSAIC), J. Geophys. Res., 113, D13204, doi:10.1029/2007JD008792, 2008.

Zhang, J. K., Sun, Y., Liu, Z. R., Ji, D. S., Hu, B., Liu, Q., and Wang, Y. S.: Characterization of submicron aerosols during a month of serious pollution in Beijing, 2013, Atmos. Chem. Phys., 14, 2887-2903, doi:10.5194/acp-14-2887-2014, 2014.

Zhang, Q., Streets, D. G., Carmichael, G. R., He, K. B., Huo, H., Kannari, A., Klimont, Z., Park, I. S., Reddy, S., Fu, J. S., Chen, D., Duan, L., Lei, Y., Wang, L. T., and Yao, Z. L.: Asian emissions in 2006 for the NASA INTEX-B mission, Atmos. Chem. Phys., 9, 5131-5153, doi:10.5194/acp-9-5131-2009, 2009.
Zhang, X., Wang, Y., Niu, T., Zhang, X., Gong, S., Zhang, Y., and Sun, J.: Atmospheric aerosol compositions in China: Spatial/temporal variability, chemical signature, regional haze distribution and comparisons with global aerosols, Atmos. Chem. Phys., 12, 779-799, doi:10.5194/acp-12-779-2012, 2012.

Zhao, C., Liu, X., Leung, L. R., Johnson, B., McFarlane, S. A., Gustafson Jr., W. I., Fast, J. D., and Easter, R.: The spatial distribution of mineral dust and its shortwave radiative forcing over North Africa: modeling sensitivities to dust emissions and aerosol size treatments, Atmos. Chem. Phys., 10, 8821-8838, doi:10.5194/acp-10-8821-2010, 2010.

Zhao, C., Liu, X., Leung, L. R., and Hagos, S.: Radiative impact of mineral dust on monsoon precipitation variability over West Africa, Atmos. Chem. Phys., 11, 1879-1893, doi:10.5194/acp11-1879-2011, 2011.

Zhao, X. J., Zhao, P. S., Xu, J., Meng, W., Pu, W. W., Dong, F., He, D., and Shi, Q. F.: Analysis of a winter regional haze event and its formation mechanism in the North China Plain, Atmos. Chem. Phys., 13, 5685-5696, doi:10.5194/acp-13-5685-2013, 2013. 